\title{
Health and welfare in organic livestock production systems - a systematic mapping of current knowledge
}

\author{
Magdalena Presto Åkerfeldt (D) - Stefan Gunnarsson (D) - Gun Bernes (D) - Isabel Blanco-Penedo (i)
}

Received: 27 March 2020 / Accepted: 13 November 2020 /Published online: 25 November 2020

(C) The Author(s) 2020

\begin{abstract}
This review aimed to systematically map and summarize the status of animal health and welfare in organic production. The prevalence of diseases and behavioural effects in organic dairy cow, beef cattle, sheep, pig, laying hen and broiler chicken were discussed in the context of the organic values and current knowledge on animal health and welfare. In total 166 peer-reviewed scientific publications between 2008 and 2020 were included. No strong evidence for neither inferior nor distinctly higher animal welfare in organic compared with conventional production could be supported. The welfare status of organic livestock is in general good in relation to the OIE definition of animal health and welfare. However, organic systems are still facing several challenges related to animal health and the arising of goal conflicts due to management and practical implications. Greater possibilities to perform
\end{abstract}

M. P. Åkerfeldt ( $\bowtie)$

Department of Animal Nutrition and Management, SLU, Swedish University of Agricultural Sciences, Uppsala, Sweden

e-mail: magdalena.akerfeldt@slu.se

S. Gunnarsson

Department of Animal Environment and Health, SLU, Swedish

University of Agricultural Sciences, Skara, Sweden

G. Bernes

Department of Agricultural Research for Northern Sweden, SLU, Swedish University of Agricultural Sciences, Umeå, Sweden

I. Blanco-Penedo

Department of Clinical Sciences, Unit of Veterinary

Epidemiology, SLU, Swedish University of Agricultural Sciences, Uppsala, Sweden species-specific behaviours in organic production systems, however, indicate that the organic standards offer a good framework for high animal welfare management. For organic dairy farmers, the main health problems are similar to those of non-organic farms; especially mastitis and lameness need improvement. Parasites, together with mastitis and lamb mortality, are important welfare issues in organic sheep production. Piglet mortality, leg problems, parasite load and increasing respiratory problems are of major relevance in organic pig production. For organic laying hens, major health challenges relate to feather pecking and cannibalism, parasites and possibilities to express species-specific behaviours. For organic broilers, dermatitis of footpads, hocks and breast are reported as main health issues.

Keywords Animal welfare - Organic farming standards · Systematic review $\cdot$ Health indicators

\section{Introduction}

Organic animal production has experienced a rapid development that also has led to changes in the way the production is conducted. The goals and principles of organic production throughout Europe are well defined, and the marketing of certified organic products is thoroughly regulated by the European Union since the 1990s and thereafter revised accordingly (EU 2018). The production is based on a setup of general principles established by the International Federation of Organic Agriculture Movements (IFOAM 2005). Concerning 
animal health and welfare, the principle implies the maintenance of physical, mental, social and ecological well-being as well as the absence of diseases. The IFOAM principles are reflected in the European regulation of organic production (EC 2008), which also includes high animal welfare standards, in particular when it comes to meeting animals' species-specific behavioural needs and protecting their health. The regulation is the fundament for the national certification within the EU member states, even if the flora of certifications may be diverse and differ between countries (Sanders 2013). Although the fundamental rules of organic production are legally defined, organic livestock production covers a broad diversity of production systems varying both between and within countries and animal species. The development of the organic sector, from the early 1970s until today, has resulted in changes in both how the production system is performed as well as the view of the production. From being a movement based on ideological thoughts, it has progressed to be defined as a production method by minimum standards, which limit the possibilities to provide a clear frame to characterize in dissociation to conventional production. Consumers expect high animal health and welfare in organic farming, but there are also doubts whether these systems achieve this better than conventional animal husbandry systems do (Sundrum et al. 2010; Sutherland et al. 2013).

Health and welfare may be defined differently, and these definitions may then have different implications (Gunnarsson 2006). Internationally, the World Organisation for Animal Health (OIE 2019) provides the most accepted definition of animal health and welfare meaning "the physical and mental state of an animal in relation to the conditions in which it lives and dies." It covers "the five freedoms": (1) freedom from hunger, malnutrition and thirst; (2) freedom from fear and anxiety; (3) freedom from heat stress or physical discomfort; (4) freedom from pain, injury and disease; and (5) freedom to express normal patterns of behaviour. There is no reason to define animal health and welfare in organic animal husbandry in a different manner than in conventional. However, according to the organic values and understanding of animal welfare, the IFOAM principles focus more and more on the animals' quality of life and emphasize the emotional state of the animal, as well as the concept of "naturalness" as part of animal welfare. Organic animals should, for example, be provided with conditions for living a natural life in accordance with their physiological and behavioural conditions and well-being, in an environment that most closely resembles that to which the species is evolutionarily adapted. Animals' ability to live a natural life is thereby considered as a prerequisite for good animal welfare (IFOAM 2005; EU 2018). That is, animal health promotion strategies aim to go beyond targeting specific disease conditions and aim at reaching a state of homeostasis (Vaarst and Alrøe 2012). Within the fundamental ideas of organic production that are based on an ecocentric view, natural living is seen as a value in itself and fulfils a higher rank than the absence of pain and suffering (Lund and Algers 2003). Ecological resilience is considered as a superior goal, and emphasis is put on system-thinking rather than on situations for individual animals (Verhoog 2000), and to reach a natural living, some negative experiences for the individual may be accepted (Verhoog et al. 2004). Sustainable agriculture is seen as multifunctional, where animals provide not only feed but also serve to cultivate farmland to preserve biodiversity and ecosystems services as open landscape. The system as such might thereby imply conflicts with health and welfare (Öhlund et al. 2017), especially between that of the system and that of the individual animal, e.g. leg health or parasite burden of free-ranging animals. This might be an underlying factor to the criticism about animal welfare in organic production, but the criticism may partly also depend on different ethical positions and views and a lack of dialogue between stakeholders (Lund and Algers 2003; Duval et al. 2016; Krieger et al. 2020).

The development of the organic sector and demands of improved animal health and welfare has led to investigations in the field to increase the knowledge and identify risk factors. However, the results are diverse, and some inconsistent interpretations of the outcome of the research might probably depend on differing research objectives and criteria (i.e. comparing organic vs. conventional production systems), heterogeneity of regions, production and farm conditions, inadequate experimental design, as well as the too low number of farms included. The variation within organic production between farms and regions as well as national differences in the interpretation of the regulation also need to be considered when comparing organic livestock systems with each other and with conventional ones (Zoiopoulos and Hadjigeorgiou 2013). Despite an increasing number of epidemiological studies in recent years, where more farm-specific factors have been 
examined, outcome-oriented animal health and welfare indicators are still requested (Darnhofer et al. 2010; EFSA 2012; Sundrum 2014). Some systematic reviews with comparative assessments of animal welfare with regard to the differences between organic and conventional farming have also been performed (Sundrum 2001; Hovi et al. 2003; Lund and Algers 2003; van Wagenberg et al. 2017). However, the fact that organic livestock systems and management change over time implies continuous revision. It is essential to include a broader discussion about what the reference system should be, with respect to current knowledge on animal health and welfare, legislative rules, consumer and producer expectations, previous and future situations, all in the context of the fundamental organic values, goals and principles.

The general objective of this review was therefore to map and summarize the status of animal health and welfare in organic dairy cow, beef cattle, sheep, pig, laying hen and broiler chicken production systems. The review focuses on prevalence of diseases and behavioural effects for the different animal categories, respectively, with the ambition to discuss the results in the context of the fundamental organic values and current knowledge on animal health and welfare.

\section{Material and methods}

\section{Definitions of the literature review}

The literature review focused on specific health and welfare indicators for different animal categories: dairy cow, beef cattle, sheep, pig, laying hen and broiler chicken. Livestock production not certified according to any organic certification scheme was referred to as conventional (Mie et al. 2017). Year 2008 was set as starting point for the search period as a new commission regulation with detailed rules for the implementation of the organic regulation was applied at that time (EC 2008). The different categories of health and welfare indicators that were chosen to be included in the review were mastitis, metabolic disorders, nutrition deficiencies and digestive disorders, reproductive disorders, foot/hoof/leg disorders, external and internal parasites, respiratory diseases, skin and tail lesions, abscesses, feather pecking and cannibalism and behavioural parameters.
Search of literature

The review included peer-reviewed scientific literature published between the 1st of January 2008 and the 16th of January 2020. The same search items on four search engines were used: (1) Web of Science Core Collection, (2) CABI, (3) Medline and (4) Scopus. The search was constructed according to a PIO approach (Population, Intervention and Outcome). Specific (for each animal category respectively) and general (common for all animal categories) paragraph search terms were articulated due to the possible search terms typically used in each area. The search terms were defined in collaboration with a professional librarian specialized in scientific databases. Since the word "organic" is used in many different contexts and there is no term consistently and collectively used in the literature for the measures that we wanted to investigate, the effect of the searches had to be quite extensive to capture the relevant papers. The final search terms are presented in Table 1. The search was performed by the same person in one database at a time for the categories "dairy cows and beef cattle", "sheep", "pigs", "laying hens and broiler chickens", respectively, on two occasions. A first search covered literature between the 1 st of January 2008 and the 31st of March 2019. An update of the search was performed on the 16th of January 2020, just before completion of the manuscript, using the same search terms but restricting the search to the time period after the original searches were performed, thus including literature between the 1st of April 2019 and the 16th of January 2020. Relevant references found through the update were included in the review.

After a first search, the duplicated outcomes were removed, using the tool "deduplicate references" in Endnote, and again manually to double-check. Then, additional refining of the search results was performed using the screening tool "Rayyan" (Ouzzani et al. 2016). Publications that were obtained in the different searches were then sorted further in order to remove a large number of off-topic publications. The selection criteria for this sorting were set up prior to the search, and publications that were not about livestock or the specific animal categories were deleted. For this review, papers on non-relevant topics, i.e. nutrition, productive performance, product quality (e.g. weight gain, carcass traits, milk and egg quality) were also sorted out. Additionally, papers concerning genetic expression, breeding goals, life cycle analysis, environmental effects, public health, 
Table 1 Approach and structured steps used to conduct the systematic search of the literature

\begin{tabular}{|c|c|c|c|c|}
\hline \multirow{2}{*}{$\begin{array}{l}\text { Paragraph } \\
\text { search terms }\end{array}$} & \multicolumn{4}{|l|}{ Animal category } \\
\hline & Dairy cows and beef cattle & Sheep & Pigs & $\begin{array}{l}\text { Laying hens and broiler } \\
\text { chickens }\end{array}$ \\
\hline $\mathbf{P}=$ Population & $\begin{array}{l}\mathrm{TS}=(\text { bovine or cattle or cow } \\
\text { or cows or heifer* or beef* } \\
\text { or suckler* or dairy or } \\
\text { calve* or calf*) }\end{array}$ & $\begin{array}{l}\text { TS }=(\text { Ovine* OR sheep* OR } \\
\text { ewe* OR hogget* OR } \\
\text { lamb or lambs) }\end{array}$ & $\begin{array}{l}\mathrm{TS}=\text { (porcine OR pork OR } \\
\text { pig OR pigs OR swine OR } \\
\text { "sow" OR "sows" OR } \\
\text { gilt* OR piglet*) }\end{array}$ & $\begin{array}{c}\mathrm{TS}=(\text { hen or hens or pullet or } \\
\text { pullets or chicken or } \\
\text { chickens or broiler or } \\
\text { broilers or poultry) }\end{array}$ \\
\hline $\mathbf{I}=$ Intervention & $\begin{array}{l}\text { TS }=((\text { organic or extensive*) } \\
\text { NEAR/2 (agricult* or } \\
\text { farm* or breed* or "bred" } \\
\text { or pasture* or pastor* or } \\
\text { system* or rear* or feed- } \\
\text { stuff or cows or beef or } \\
\text { production) or freerange } \\
\text { or graz* or roughage or } \\
\text { "grass silage" or (housing } \\
\text { near/1 system*) }\end{array}$ & $\begin{array}{l}\text { Sheep: TS }=((\text { organic OR } \\
\text { extensive*) NEAR/2 } \\
\text { (agricult* OR farm* OR } \\
\text { breed* OR "bred" OR } \\
\text { system* OR rear* or pro- } \\
\text { duction or lamb* or } \\
\text { sheep* or mutton or wool } \\
\text { or fleece*) OR } \\
\text { TS=(pasture* or bedding } \\
\text { or bedded or "sheep } \\
\text { flock*") }\end{array}$ & $\begin{array}{c}\text { TS=((organic or extensive*) } \\
\text { NEAR/2 (agricult* OR } \\
\text { farm* OR breed* OR } \\
\text { "bred" or pasture* OR } \\
\text { pastor* OR system* OR } \\
\text { rear* OR feedstuff OR } \\
\text { pigs OR pork or produc- } \\
\text { tion) OR freerange OR } \\
\text { graz* OR roughage OR } \\
\text { "grass silage" OR (hous- } \\
\text { ing near/1 system*)) }\end{array}$ & $\begin{array}{l}\text { TS }=((\text { organic or extensive*) } \\
\text { NEAR/2 (agricult* or } \\
\text { farm* or breed* or "bred" } \\
\text { or pasture* or pastor* or } \\
\text { system* or rear* or feed* } \\
\text { or egg or eggs or chicken } \\
\text { or poultry or broiler* or } \\
\text { hen or production) or } \\
\text { freerange or "free range" } \\
\text { or molt* or outdoors or } \\
\text { veranda or aviar* or } \\
\text { perch* or (housing near/1 } \\
\text { system*) }\end{array}$ \\
\hline
\end{tabular}

$\mathbf{O}=$ Outcome $\quad \mathrm{TS}=($ health OR welfare OR disease* OR infection* OR bacteri* OR disorder* OR injurie* OR zoono* OR mortality OR longevity OR liveability OR pathogen* OR phatologic* OR behavio* OR stereotyp* OR culling* OR metabolic* OR perform* OR producti* OR reproducti* OR fertility OR parasite* OR gastrointestin* OR nematode* OR endoparasit* OR ectoparasit* OR trematode* OR "body condition*"

\begin{tabular}{|c|c|c|c|c|}
\hline $\mathbf{O}=$ Outcome & $\begin{array}{l}\text { TS=(milk* OR yield* OR } \\
\text { perform* OR "production } \\
\text { level*" OR "physiological } \\
\text { status" OR "metabolic } \\
\text { change*" OR "metabolic } \\
\text { status" OR "mineral } \\
\text { imbalance" OR "oxidative } \\
\text { stress" OR lameness OR } \\
\text { locomotion OR ketosis } \\
\text { OR claw or claws OR hoof } \\
\text { or hooves OR "somatic } \\
\text { cell count*" OR mastit* } \\
\text { OR dystocia* OR } \\
\text { "retained placenta" OR } \\
\text { "lung worm*" OR } \\
\text { pneumonia OR "calving } \\
\text { interval*" OR } \\
\text { "insemination index" OR } \\
\text { "Fat-to-protein ratio") }\end{array}$ & $\begin{array}{l}\text { TS=("weak lamb*" OR } \\
\text { hypothermia OR } \\
\text { locomot* OR acidosis OR } \\
\text { mastitis OR "somatic cell } \\
\text { count*" OR "lung worm" } \\
\text { OR "liver fluke" OR } \\
\text { pneumonia OR scab* OR } \\
\text { "lamb* interval" OR orf } \\
\text { OR brucellosis OR footrot } \\
\text { OR maedi OR clostridi* } \\
\text { OR scrapie OR } \\
\text { mycoplasma OR "fly } \\
\text { strike" OR "pregnancy } \\
\text { toxaemia" OR } \\
\text { hypocalcemia OR } \\
\text { hypomagnesemia OR } \\
\text { dystrophy OR } \\
\text { dermatophilosis OR } \\
\text { enterotoxemia OR } \\
\text { perfringens OR tetanus } \\
\text { OR coccidiosis OR } \\
\text { "poisonous plants") }\end{array}$ & $\begin{array}{l}\text { TS=("post partum } \\
\text { dysgalactia syndrome" } \\
\text { OR "postpartum } \\
\text { dysgalactia syndrome" } \\
\text { OR mastit* OR farrow* } \\
\text { OR oestrus OR estrus OR } \\
\text { weaning* OR diarrhea OR } \\
\text { diarrhoea OR lame* OR } \\
\text { locomot* OR } \\
\text { osteochond* OR arthritis } \\
\text { OR erysipelas OR joint* } \\
\text { OR leg OR legs OR "tail } \\
\text { bit*" OR "skin lesion*" } \\
\text { OR mycoplasma OR } \\
\text { actinobacillus OR } \\
\text { pneumonia OR enteritis } \\
\text { OR pleurit* OR ascaris* } \\
\text { OR "white spot*" OR } \\
\text { growth OR root* OR } \\
\text { forag* OR explorat* OR } \\
\text { activity OR "active } \\
\text { behavio*" OR "social } \\
\text { interaction*" OR biting* } \\
\text { OR aggressi*) }\end{array}$ & $\begin{array}{l}\text { TS=("laying rate*" OR } \\
\text { "mineral imbalance" OR } \\
\text { leg OR legs OR lame* OR } \\
\text { salpingitis OR "claw } \\
\text { lesion*" OR parasit* OR } \\
\text { nematode* OR coccidi* } \\
\text { OR eimeria OR } \\
\text { salmonella OR } \\
\text { campylobacter OR mite* } \\
\text { OR clostridia* OR } \\
\text { mycoplasma OR ascites } \\
\text { OR infecti* OR "injurious } \\
\text { peck*" OR "feather } \\
\text { peck*" OR cannibalism } \\
\text { OR "keel bone*” OR } \\
\text { fracture* OR aggressi* } \\
\text { OR dustbath* OR “dust } \\
\text { bath*" OR "sand bath*” } \\
\text { OR sandbath* OR perch } \\
\text { or perches OR scratch* } \\
\text { OR thinning OR catch* } \\
\text { OR virus* OR viral) }\end{array}$ \\
\hline
\end{tabular}

food safety, working environment, evaluation of biological indicators for different diseases, biosecurity and diagnostics were excluded. To enable a focus on studies conducted on production systems in similar economic contexts, studies performed or describing situations outside the European Union, North America or Canada were excluded. As a second step, all titles and abstracts of the search outcomes for each animal category, respectively, were read by the co-authors, and a further selection was made. Thus, relevant papers were 
identified and included in the review by co-authors with expertise in the different livestock species. The search and sorting process is presented in Fig. 1.

\section{Results—systematic search}

\section{Database outcome}

The literature search gave a large number of publications (17,056 in total), but throughout the review process, most of them were excluded as they did not fulfil the inclusion criteria (Fig. 1). After the final selection, in total 166 publications (44 publications on dairy and cattle, 30 on sheep and lamb, 57 on pigs, 14 on laying hens and 21 on broiler chickens) were relevant to include as results of the systematic search.

Dairy cow and beef cattle production

The most common and important diseases investigated in organic dairy cows are mastitis, infertility, metabolic disorders and lameness. The number of studies addressing organic beef cattle is very limited and focuses on general health and welfare.

\section{Mastitis}

Udder health is the most commonly described health trait in scientific literature on organic dairy production since it constitutes one of the biggest health problems. Krieger et al. (2017) reported that the median prevalence for subclinical mastitis on 192 organic dairy farms in Germany, Spain, France and Sweden was 51.3\% (interquartile range $=15.4$ ). Different results have been reported for udder health when organic and conventional dairy herds were compared. An indirect indicator of udder health and mastitis is somatic cell count (SCC). When comparing SCC on organic dairy farms, with conventional farms, there are a lot of controversies at the different studies. There are findings of a positive deviation (Richert et al. 2013a; Levison et al. 2016), negative (Slagboom et al. 2016) or similar (RodriguezBermudez et al. 2017) outcomes. Although SCC has been compared in organic and conventional systems worldwide, antibiotic usage has not been extensively taken into consideration. Studies that fail to consider other factors than the farming system (organic vs. conventional) could have caused or contributed to the reported differences. Factors explaining the higher cow milk SCC in organic farms could be avoidance of antibiotic treatments for mastitis, and lower milk yield in general, compared with conventionally kept dairy cows, in addition to differences in management practices (Schwendel et al. 2015). Besides, mastitis is the most frequently treated, recorded and mentioned disease in both conventional and organic dairy herds, and its therapy accounts for a very large proportion of the antibiotic drugs used in the farm. The lower treatment rate and, thus, reduced use of antibiotics may reduce antibacterial selection pressure. Garmo et al. (2010) investigated antibiotic resistance in udder pathogens from milk samples obtained from cases of clinical mastitis. They reported no difference between conventional and organic Norwegian red cows in quarter samples positive for mastitis bacteria and found that few $S$. aureus isolates resistance to penicillin in both management systems. Maintaining animal health without the use of therapeutic interventions is a major challenge for organic dairy farmers, including the reduction of the (preventive) use of antibiotics. For example, the approach to dry cow therapy (DCT) in organic farming differs from the practices on conventional farms. The necessity of application of DCT on cows in organic farms has however been addressed very little in research. Routine use of DCT is not allowed according to the organic regulations (and selective DCT is only permitted on individual animals, and cows will be treated after diagnosis), while it is a widespread habit in conventional farming systems in some parts of the world (Poizat et al. 2017). Bennedsgaard et al. (2010) concluded that antibiotic udder treatments may be reduced without apparent negative effects and that the control measures for SCC used on organic farms are at least as effective as those on conventional farms in controlling SCC. In this sense, preventive management practices are important in any dairy farm, but especially on organically managed farms. This is because the availability of products to treat a disease is limited (Stiglbauer et al. 2013), and all diagnostic measures and animal care at drying off aim to improve mammary gland health regardless of the farm system (Müller and Sauerwein 2010).

\section{Metabolic/digestive disorders}

The major interest regarding metabolic disorders in organic dairy production has been connected to the 
metabolic challenges in fulfilling the energy requirements of cows using forage-based diets. In a study of organic dairy herds in four European countries, the median prevalence for the risk of ketosis and acidosis were $10.0 \%$ (interquartile range $=7.7$ ) and $3.2 \%$ (interquartile range $=4.7$ ), respectively (Krieger et al. 2017). Concern has been expressed that many organic farms, particularly those that have converted recently, may have cows that are genetically selected for high milk yield and that an organic diet may not meet these animals' requirements (Leiber et al. 2015). The major concern, however, is the risk of severe negative energy balance in cows in early lactation, due to the relatively low proportion of concentrate feed when following the organic legislation (Flaten and Lien 2009; BlancoPenedo et al. 2012a). However, according to studies made by Blanco-Penedo et al. (2012a) and Richert et al. (2013a), there was no evidence that organic cows were metabolically more challenged or had a severe negative energy balance.

Animal nutrition in organic farming is highly dependent on local geographical conditions, and mineral deficiencies may occur in certain areas due to low mineral content or bioavailability of some trace elements in the soil. This can be associated with mineral imbalances in the diet due to the regulated restricted level of concentrate in the diet (EC 2008), although mineral feed additives can correct it. Despite this, organically managed animals could face an enhanced risk of mineral or nutritional deficiencies in areas with soil mineral deficiency. Compared to other farm systems, husbandry practices largely determine essential trace element status of organic livestock, as reported both for dairy (BlancoPenedo et al. 2014) and beef cattle (calves and young cattle) (Blanco-Penedo et al. 2009). No signs of severe deficient concentration of essential elements have however been observed in organic dairy herds (BlancoPenedo et al. 2014; Orjales et al. 2018) or organic beef farms (Blanco-Penedo et al. 2009). A high activity of the liver specific enzyme aspartate aminotransferase (GOT) in calves may indicate slight liver damage due to acidic conditions associated with the diet and may be a contributing factor of metabolic disorders in the fattening period. According to Blanco-Penedo et al. (2008), however, the GOT activity and activity of glutamate dehydrogenase and creatine kinase in beef calves from different production systems in Spain were within acceptable ranges, although a strong positive correlation was observed between the GOT activity and the proportion of concentrate in the diet.

\section{Lameness and foot/hoof/leg disorders}

Lameness is highly prevalent in today's dairy and beef farming, and it negatively affects the well-being of animals. Numerous factors significantly influence the prevalence of lameness. According to Rutherford et al. (2009), organic management reduced herd lameness, due to the combination of different organic management practices. In their study, practices such as grazing and type of housing resulted in unique features determining the cows' foot and leg health condition. On the other hand, some authors in the USA have stated that management factors differ significantly between organic and conventional dairy farms and that this is a confounding factor on the incidence of lameness. For example, a study on 292 herds showed prevalence of lameness ranging from 0 to $54 \%$ (mean $8 \%$ ), and it did not differ among grazing systems (conventional non-grazing

\begin{tabular}{|c|c|c|c|}
\hline $\begin{array}{c}\text { Dairy cows and } \\
\text { beef cattle }\end{array}$ & Sheep & Paying hens and \\
broiler chicken
\end{tabular}

Fig. 1 Flow diagram documenting studies included in the review 
herds compared with organic and conventional herds with grazing practices) (Richert et al. 2013b). In another study by von Keyserlingk et al. (2017), the prevalence of lameness was lower on organic farms compared to non-organic farms, where fewer than $5 \%$ of the lactating cows had access to pasture during the grazing season. In European studies, prevalence estimates of lameness has been reported to range from 19 on organic farms in Germany (Leach et al. 2010) to $31 \%$ in Simmental dairy herds in Austria (Dippel et al. 2009) and 36\% in UK herds (Barker et al. 2010). A recent EU project presented median herd prevalence of lameness in organic herds of $25 \%$ (range $0-51 \%$ ), 20\% (range 0-79\%), 10\% (range $0-27 \%$ ) and $5 \%$ (range $0-25 \%$ ) in France, Germany, Spain and Sweden, respectively (Sjöstrom et al. 2018).

Hock lesions in dairy cows are a common welfare problem. The prevalence of hock injuries on 40 organic and non-organic UK farms was on acceptable levels for cow comfort on many of the farms (Rutherford et al. 2008); however, organic farms had lower prevalence of hock lesions compared with non-organic farms (37.2 vs. $49.1 \%)$. Moreover, cows housed in free stalls with cubicles had a higher prevalence of hock lesions than those housed on straw bedding (46.0 vs. 25.0\%). In a data set of 2922 lactating dairy cows (64 conventional and organic dairy farms with Holstein Friesian cows in Germany and 31 conventional dairy farms with the dual purpose breed Fleckvieh in Austria), it was found that the prevalence of integument alterations at hocks and carpal joints was high on all farms (Brenninkmeyer et al. 2016).

\section{Respiratory diseases}

Very little research has been performed on respiratory disorders in organic cattle and calves. No differences between conventional and organic dairy herds in prevalence of or incidence risk for certain viruses, such as bovine respiratory syncytial virus (BRSV) or bovine coronavirus (BoCV), have been described (Wolff et al. 2015). In organic beef cattle, results from logistic regression models of the appearance of the most common condemnations at Spanish slaughterhouses during 1 year revealed that organic calves had lower risk of lung condemnations compared with those from conventional farms (Blanco-Penedo et al. 2012b).

\section{Parasite infections}

Parasite infection constitutes one of the most important constraints on the welfare, health and productivity of grazing cattle in temperate regions (Charlier et al. 2009). Research in this topic has been performed across Europe in grazing systems with the major aims to assess prevalence and study the detrimental impact and the use of various diagnostic markers (Höglund et al. 2010; Ellis et al. 2011) and the impact of the infections on individual performance (May et al. 2017). The prevalence of liver fluke infection in a Swedish study performed 2008 was low, and it was only diagnosed in $7 \%$ of the 105 organic and 6\% of the 105 conventional herds (Höglund et al. 2010). The incidence, however, has increased dramatically since then (Novobilský et al. 2015). Organic farms did not have higher milk antibody levels for Fasciola hepatica than previous data reported from conventional farms in Spain (Orjales et al. 2017). Prevalence of helminth parasites in 114 organic herds in the USA were described to be low, based on low faecal egg counts (FEC) with only a few heifers with > 500 eggs per gramme faeces (EPG) (Sorge et al. 2015). In that study, egg counts of gastrointestinal parasites did not differ significantly between organic and conventional dairy herds, with the exception of significantly more strongyle-type eggs in organic compared to conventional herds (Sorge et al. 2015). According to a multivariable model approach in Sweden by Silverlås et al. (2009), similar prevalence of cryptosporidium was found in organic and conventional herds, both in dairy calves (44.7\% vs. $52.3 \%$ ) and cows (low due to development of immunity).

\section{Behavioural effects}

There is little research on the impact of organic regulations on cow welfare. No specific studies on the affective state or naturalness for organic cattle were found in this literature search. The relevance of behaviour in the context of naturalness and cow welfare is however brought up in the discussion of this review. Welfare and productive performance of dairy cows organically reared in plains or hilly areas in Italy was assessed with the animal need index ANI-35-L system (Bartussek et al. 2000) in a study by Martelli et al. (2010). The results indicated that, in the large majority of cases, organic dairy production successfully combines good levels of productivity, animal health and animal welfare. 
This was also found in Slovakian organic farms under extensive management (Kottferova et al. 2014). In a study on 30 low-input and organic dairy systems in three countries (using the Welfare Quality Protocol), the overall welfare state on the farms was acceptable (Kirchner et al. 2014). In general, that study showed that the weak points were related to the presence of injuries and discomfort of the lying areas of the cows. Specific problems such as mutilations, poor human-animal relationship or insufficient water provision were also identified on the studied farms.

Results from the USA on the welfare status on 192 organic dairy farms were, although with large variation, on similar level as the welfare status on 36 conventional dairy farms (Bergman et al. 2014). The results were below the desirable thresholds of many criteria of the assessment programmes currently used in the US dairy sector. In organic beef cattle, a small study based on the ANI-35-L/2000 system was conducted on four organic farms located in different regions of Lithuania. The farms had deep litter or cubicle housing, and the main outcome was an effect of housing, where deep littler was evaluated more favourably in comparison with cubicle housing (Stuoge et al. 2016). A study performed in the UK (Langford et al. 2011) compared the behaviour of cows in two different housing types (free stall with cubicles vs. straw-bedded pen) during and after peak feeding time. The results showed that the behaviour of organic dairy cows was not different from conventional dairy cows, and the results suggest that most behavioural welfare problems related to housing could be alleviated by management practices.

\section{Sheep production}

The European Food Safety Authority (EFSA 2014) has reviewed health and welfare issues in sheep production. No discrimination between organic and conventional production was done, but across all systems, the most frequently identified welfare consequences for ewes were thermal stress, lameness and mastitis. Regarding lambs, thermal stress, pain due to management procedures, gastroenteric disorders and neonatal disorders were the main welfare consequences, and there were few differences among the systems of management. There is no evidence that disease problems are more severe or frequent on organic than on non-organic British sheep farms, according to Gray (2008). It is, however, not possible to make direct comparisons based on the general disease surveillance systems. No significant differences were observed between organic and conventional farms in terms of an animal needs index, as well as housing characteristics and animal-based parameters (e.g. dirtiness, overgrown hoofs, lameness, lesions, longevity), in an Italian study of 10 organic and 10 conventional sheep farms (Napolitano et al. 2009). The farms in both systems based their production on extensive grazing, and the authors hypothesize that the organic approach may be more important for the welfare of animals raised under intensive conditions, as compared to extensively reared sheep.

Kern et al. (2014) assessed animal health and body condition score (BCS) of 1562 ewes (6093 observations) on 20 German organic farms. On a remark point scale $1-5$ ( 5 being without disorders), remarks $1-4$ was found in $4.3 \%$ of the observations on legs/hooves, $4.5 \%$ on udder health and $2.6 \%$ on respiratory systems. Severe disorders (point 1 on the scale) were only found in $0.8 \%$ of the sheep regarding lameness, $3.0 \%$ for acute mastitis and $0.55 \%$ for obvious lung problems. The data was separated according to the primary purpose of the sheep, dairy, meat or landscape management, as the choice of breed mostly differs between the purposes, e.g. landraces being most common in extensive landscape management. A significant difference in BCS was found, with dairy sheep having a lower score than landrace sheep, probably because of poor nutrition.

\section{Parasite infections}

According to the studies mentioned in the section above, and several others (e.g. Cabaret and Nicourt 2009; Pilarczyk et al. 2008), parasitism by gastrointestinal nematodes (GIN) constitutes one of the biggest health problems in organic lamb production. Parasite eggs were found in $60 \%$ of 635 faecal samples from German organic sheep farms. More than one species was found in $15 \%$ of the samples. Strongyle nematodes and coccidians (Eimeria spp.) were the most common endoparasites, but also small lungworms (Metastrongylida) were found. The risk of being infected with GIN was highest for meat sheep compared to extensively held landrace ewes and sheep for dairy purpose, whereas the risk of being infected with Eimeria spp. was highest in dairy sheep systems (Kern et al. 2014). In comparisons of parasite burden between organic and conventional systems, there are varying results. In a recent Swedish investigation of 20 conventional and 19 organic farms, no significant 
differences in infection levels were observed between the systems (Höglund et al. 2019). Trichostrongylus spp. was the species with highest prevalence in both ewes and lambs, in both systems. The study also showed that Haemonchus is spread in large parts of Sweden.

In a Canadian study of 8 certified organic, 16 noncertified organic and 8 conventional farms, there was a general trend for sheep from the certified organic farms to have lower mean EPG, compared to the other farm types. In that study, the predominant nematode genera were Teladorsagia, Haemonchus and Trichostrongylus. There was a large variation in infection levels between individual sheep, where a few hosts had high FECs, while the majority had low or undetectable levels (Mederos et al. 2010). In a Polish comparison between production systems (three organic and two conventional farms), the results were the reverse (Pilarczyk et al. 2008). The mean prevalence of infection with internal parasites was $79 \%$ in sheep from the organic farms and $42 \%$ in those from the conventional farms. The prevalence of the protozoan Eimeria was almost double in the organic sheep. Also liver fluke and tapeworms were detected, on both conventional and organic farms. Liver fluke has been found in the UK to be an increasing problem that can be hard to control on organic farms (Gray 2008). In a Greek study of zoonotic parasites, no difference was seen for Toxoplasma gondii between organic and conventional farms (Kantzoura et al. 2013). In a similar study concerning risk factors for helminths and coccidia, no significant differences were observed between organic and conventional farms (Kantzoura et al. 2012). Control methods against GIN did not differ much between organic and conventional farms in a Swedish study (Höglund et al. 2019), and the majority of all the studied farms had used anthelmintics in the latest year. In addition, ectoparasites can be a problem. For example, according to Gray (2008), sheep scab in the UK is harder to handle in organic than in conventional production, due to the restrictions in use of medication.

\section{Mastitis}

One of the most important diseases in sheep husbandry is mastitis, and the SCC of milk can help identifying udder infections. In a German study, milk samples from
614 organic ewes with different primary purpose (dairy, meat or landscape management) were used to detect factors influencing SCC and assess risk factors that enhance the occurrence of bacteria in milk (Kern et al. 2013). The most common bacteria found were Staphylococcaceae $(55 \%)$ and Streptococcaceae (23\%). A log transformed SCC score was significantly lower in the extensively kept landrace ewes compared to ewes in meat and dairy systems. However, only $5 \%$ of all ewes had clinical mastitis. It was also found that meat sheep had the highest risks of udder problems, measured as occurrence of bacteria. Compared to dairy sheep, meat sheep raise their lambs, which could mean a higher stress for the udder, compared to milking. Ewes with two lambs had higher SCC than animals with only a lamb, probably due to higher sucking frequency. In addition, multiples sometimes suck from several dams, which increase the risk of spreading of bacteria between udders. In the review by EFSA (2014), mastitis was identified as an important welfare consequence, but it was identified mainly in dairy sheep, and it was stated that the occurrence is also affected by genetic factors. A tendency to lower bacteria count and SCC was identified in milk from organic farms in a Greek study including 25 organic and 25 conventional sheep and goat farms (Malissiova et al. 2017). This difference was probably due to differences in the hygienic farming practices, although there were no differences regarding the occurrence of Staphylococcus aureus and Escherichia coli. The study concluded that the milk from the organic farms had a better microbiological profile compared to that from the conventional farms.

\section{Lamb mortality}

Lamb mortality is not only costly but also an ethical issue. For the farmers, the loss of a single lamb or twins may be considered as negative, but deaths among triple lambs probably are more easily accepted. In a French study by Cabaret et al. (2011), the lamb mortality was high in both organic and conventional meat sheep farms. Also according to Verkaik (2011), lamb mortality on Dutch organic dairy sheep farms was relatively high, as the farmers rely much on self-reliance of the newborn lambs to save working time. Benoit et al. (2009) found that three lambings in 2 years in organic production were a risk factor for reproduction performance and health and thus, less sustainable, compared to one lambing per year. The system led to 
higher lamb mortality due to more stillbirths (toxoplasmosis) and higher numbers of digestivetract strongyles and coccidia.

\section{Lameness}

The risk ratio of lameness was lower on organic farms than non-organic, according to a survey among 1260 English sheep farmers (Winter et al. 2015) with around $5 \%$ organic farms included. Sheep can be lame of many different reasons, e.g. interdigital dermatitis, foot rot or contagious ovine digital dermatitis (CODD). In 2016, CODD was estimated to be present in approximately $58 \%$ of the English sheep flocks, and the prevalence of CODD on organic farms was estimated to be 0.71 , if it was 1.0 on a non-organic farm (Dickins et al. 2016).

According to a German study on organic farms, meat and dairy sheep had lower risk to get hoof problems compared to landrace sheep. Landrace sheep are common in rough environments, which may pose a higher risk for injuries (Kern et al. 2014).

\section{Behavioural effects}

In organic production, the space per animal often is larger than in conventional systems, and several studies support the fact that space is important for sheep behaviour and welfare. Increased animal density results in a reduction of space for locomotion, and greater number of animal interactions, especially of aggressive ones (Centoducati et al. 2015). According to Hansen (2015), increased indoor space contributed to better animal welfare, as indicated by increased lying time, more synchronized lying behaviour, less displacements and higher milk yield in sheep. An increasing indoor space allowance from 0.75 to $1.50 \mathrm{~m}^{2}$ /ewe had positive effects on activity and behaviour in pregnant ewes, but a further increase to $2.25 \mathrm{~m}^{2}$ /ewe had limited effects (Vik et al. 2017). When comparing indoor allowances between 0.5 and $1.5 \mathrm{~m}^{2} / \mathrm{ewe}$, it was found that the total time spent lying down was lower, and standing was higher when the area decreased (Centoducati et al. 2015). In organic production, sheep often are outdoors more than in conventional systems. When assessing the effects of providing ewes with free access to an outdoor area compared to rearing indoors with equal space allowance, it was found that access to an external paddock had beneficial effects on immune reactivity and behavioural activities of lactating ewes (Caroprese 2008).
Pig production

\section{Metabolic/digestive disorders}

Thinness or poor body condition of organic sows is a main concern in several European countries (Simoneit et al. 2012; Dippel et al. 2014; Früh et al. 2014). Weissensteiner et al. (2018) found that sows with larger litters had lower feed intake and greater weight loss during 1-2 weeks postpartum, when fed diets with high proportion of home-grown ingredients with low protein content. No effect of diet was however seen among sows with smaller litters. On the contrary, Kongsted and Hermansen (2009) found that even with a lactation length of 7 weeks or more, it was possible to avoid poor body condition at weaning in organic sows in Denmark. In addition, sows of native breeds managed under organic outdoor and indoor conditions in Poland showed satisfactory body condition (Szulc 2011). Poor body condition in fattening pigs was reported as a main problem in Danish herds (Früh et al. 2014), and studies on 101 organic sow herds in six European countries showed that diarrhoea in suckling and weaned piglets was a predominant disease (Sundrum et al. 2010). It was concluded that post-weaning diarrhoea is a relevant health and welfare problem in organic weaning and fattening pigs in many countries (Papatsiros 2011; Leeb et al. 2014; Früh et al. 2014), although, e.g. the UK reported diarrhoea as less frequent (Früh et al. 2014). Organic all-year-round outdoor systems (as compared with indoor systems with outdoor runs or semioutdoor systems) lowered the frequency of diarrhoea (Leeb et al. 2019), and the access to roughage, such as silage, had a positive effect on pigs' gastric health (Holinger et al. 2018b). In comparison with pigs only receiving straw, pigs that ate silage had an overall lower prevalence of gastric ulcers (score 6; 0.7\% compared with $6.1 \%$ ), and among the pigs with pathological damages, more severe damages, including gastric ulcers, were found in those that only received straw. The bibliography also indicates that inclusion of roughage may have potential to promote the immune competence of sows and their piglets (Werner et al. 2014).

\section{Reproductive disorders and piglet mortality}

According to Dippel et al. (2014), vulva lesions are a prevalent problem among organic sows. Reproductive disorders including MMA (metritis, mastitis, agalactia) 
were mentioned to be major health problems among organic sows in eight European countries (Früh et al. 2014). In addition, MMA was previously reported to be a predominant problem of organic sows in six European countries (Sundrum et al. 2010), with annual replacement rates of $32.4 \pm 14.3 \%$, indicating a high level of replaced sows, probably due to reproductive disorders, although the figures were lower than those from conventional farms. Piglet mortality is a relevant health and welfare problem in organic production. Sundrum et al. (2010) reported that mortality rates of organic piglets averaged $19.7 \pm 9.7 \%$ and $4.9 \pm 5.5 \%$ for pre- and postweaning, respectively. In a study from 2007/2008 comprising 1200 litters from seven Danish organic sow herds, the mean total pre-weaning mortality amounted to as much as $33 \%$, although ranging from 25 to $40 \%$ between herds (Sørensen and Pedersen 2013). A main concern is that a majority of deaths occurs within the first 4 days after farrowing, which affects the total number of weaned piglets (Lindgren et al. 2013; Prunier et al. 2014; Leeb et al. 2019), but according to Wallenbeck et al. (2009a), organic piglets in Sweden died at a higher age compared with conventional ones. Total loss of suckling piglets was found to be around $20 \%$ among 74 farms in eight countries, and did not differ between organic systems (outdoor all-year-round, semi-outdoor systems and indoor housing with outdoor run) according to Leeb et al. (2019). The number of stillborn piglets was found to be higher among organic sows compared to conventional ones, according to Lindgren et al. (2013). Large litters together with increasing parity were identified as risk factors for stillbirth (Rangstrup-Christensen et al. 2017) as well as for piglet mortality and early crushing of piglets in Danish organic herds (Rangstrup-Christensen et al. 2018a, b).

\section{Respiratory diseases}

According to the description of organic pig production in Europe by Früh et al. (2014), organic fattening pigs had better lung scores than conventional pigs in Austria, while respiratory diseases were described as main health problems for organic weaning and fattening pigs in Denmark, France, Germany and Switzerland. According to a review by Simoneit et al. (2012), pigs in organic indoor systems with outdoor access had respiratory illness in similar levels as those in conventional systems. All-year-round outdoor systems, however, showed lower prevalence of respiratory problems compared to organic semi-outdoor systems and indoor housing systems with outdoor runs (Leeb et al. 2019). The risk for chronic pneumonia and pleuritic in organic/ free-range vs. conventional pigs was found to be equal, according to records on a large Danish abattoir (Alban et al. 2015). Airway infection was also the most prevalent disease complex (within-herd prevalence of approximately 20\%) in organic and conventional free range systems, and did not differ from conventional indoor systems (Kongsted and Sørensen 2017).

\section{Lameness/leg/foot health}

Lameness of sows was less prevalent in organic compared to conventional herds (Dippel et al. 2014; KnageRasmussen et al. 2014) and less prevalent in all-yearround and partly outdoor sow housing systems compared to indoor systems (Leeb et al. 2019). However, according to Früh et al. (2014), all European countries involved in the study (Denmark, Germany, Italy, Sweden, Switzerland and the UK), reported leg problems (i.e. unspecified, injuries or joint problems) in organic sows as a major health problem. In the same study, leg and joint problems were identified as major health issues also among organic fattening pigs in some countries (Sweden, Italy and Germany).

The prevalence of auxiliary bursae (due to mechanical stress of the extremities) and injuries of claws was studied in 948 conventionally and 58 organically raised pigs, in four abattoirs in Southern Germany. Significantly lower and less severe prevalence of bursas and less injuries of claws were found among organically reared fattening pigs compared to conventional ones (Gareis et al. 2016). However, chronic infectious arthritis was more prevalent in organic/free range vs. conventional fattening pigs (Alban et al. 2015). It was suggested that this could be due to higher risk for erysipelas infections (Erysipelothrix rhusiopathiae), poorer hygiene (thus a higher general infection pressure) or more mechanical stress and joint injuries, predisposing the joint to arthritis. Lindgren et al. (2014) found more joint lesion slaughter remarks in organic pigs. Kongsted and Sørensen (2017) also found that organic and conventional free-range systems, with a larger space allowance and outdoor access, increased the risk of arthritis prevalence compared to conventional indoor systems. Further, Etterlin et al. (2014) found higher prevalence and severity of osteochondrosis lesions in the elbow and hock joints of fattening pigs allowed to range freely, 
compared to pigs kept in confined housing. However, even though free ranged (e.g. comparable with organic housing) fattening pigs had higher prevalence and more severe lesions than indoor confined pigs, lameness was not detected at a higher level. This indicates that the pigs may be less clinically affected as exercise may help strengthen the joint supportive tissues and lower the pain (Etterlin et al. 2015). According to Wallenbeck et al. (2020), the total incidence of joint rejections at slaughter was very low among Swedish organic slaughter pigs $(1.3 \%)$, but the proportion of pigs with nonnormal locomotion and lameness was high at $24 \mathrm{w}$ of age (33.7 and $25.2 \%$, respectively) and was increasing from w 13-24. In combination with the use of modern pig breeds, extensive and outdoor housing systems might be an underlying risk for leg health problems. The results from Wallenbeck et al. (2020) did however not support any evidence that leg health in Swedish commercial organic herds would be improved by changing sire breed from the commonly used sire breed Hampshire to Duroc.

\section{Parasite infections}

Endoparasites are common and more prevalent among organic pigs or pigs with access to outdoor areas, compared to conventional indoor pigs (Früh et al. 2014; Lindgren et al. 2014; Alban et al. 2015; Katakam et al. 2016; Kongsted and Sørensen 2017). Especially, higher level of Ascaris suum infections is common both before and after weaning and consequently with a higher prevalence of milk-spotted liver in organic pigs at slaughter. In spite of a more professional management of organic herds during the 1990s up to 2000, Leeb et al. (2014) found that organic weaners in Denmark were still heavily infected by A. suum. In an Austrian study, $69.5 \%$ of faecal samples from organic fattening farms were positive for A. suum (Kreinocker et al. 2017). According to Roepstorff et al. (2011), the long-lived eggs of A. suum and $T$. suis are a great challenge in organic pig herds and that even a 2-3-year pasture rotation programme may not be enough. Larger scale production systems based on indoor housing could further favour helminth transmission (Roepstorff et al. 2011). In addition, ectoparasites have been reported to be a general health problem on organic farms both in Austria and the UK (Früh et al. 2014). Lindgren et al. (2014) confirmed that mange, Sarcoptes scabiei, was the most important ectoparasite, causing skin lesions, restlessness and itching. In contrast, Leeb et al. (2019) observed very few signs of ectoparasites in a study with different systems (all-yearround outdoor, partly outdoor and indoor with outdoor run) in Austria.

Lesions and abscesses (skin, tail, body) and contagious diseases

Scar/hock lesions, abscesses in leg/toe, hernia and pyemia were found to be of lower risk in organic/free range compared with conventional systems, in a comparison of lesions found during meat inspection in Denmark. Abscesses on the mid and hind part of the body, old fractures, osteomyelitis and tail lesions were instead found to be more frequent in organic vs. conventional herds, whereas abscesses in head and ears and fresh fractures were similar across systems (Alban et al. 2015). Similar results were found by Kongsted and Sørensen (2017), who reported higher incidences of several lesions, e.g. tail lesions, skin lesions, bone fractures, septicaemia and abscesses, but lower prevalence of leg swellings, hernia and hoof abscesses in organic and conventional free-range pigs, compared with conventional indoor pigs at slaughter.

Important emerging pathogens are Clostridium difficile and different salmonella infections that cause enteric and clinical diseases in pigs, followed by diarrhoea. A Dutch investigation, both on individual pig level and on herd level, did not find any difference between the prevalence of $C$. difficile in pigs derived from conventional or organic farming types (Keessen et al. 2011). Hoogenboom et al. (2008) reported incidence of salmonella in samples of organic pig faeces at similar levels as for conventional ones. Interestingly, at farms that had converted to organic production more than 6 years before the study, no salmonella was detected. This was supported by Gosling et al. (2018) who found lower prevalence of $S$. typhimurium in outdoor than indoor farms in Great Britain. According to Astorga et al. (2010), the prevalence rates for Salmonella spp. was in general low among Iberian pigs in free-range systems. Similarly, detection of antibodies for salmonella in faecal samples from 59 Austrian organic pig farms was low (Kreinocker et al. 2017). A significantly higher risk of infection of toxoplasmosis (T. gondii) was however found for pigs with access to pasture (Wallander et al. 2016). Most infections in swine are subclinical but can cause clinical signs in pigs of all ages with health disorders as a result. 


\section{Behavioural effects}

In organic production, the use of farrowing crates is not allowed (EC 2008). The effects on sow and piglet behaviour in classic farrowing crates in comparison with alternative farrowing systems, such as loose housing, are well investigated and described in the literature, but no bibliography of differences between organic and non-organic systems was found, and therefore this is not covered by the search results. However, as it has a major effect on sow and piglet behaviour and welfare, the subject is included in the discussion of this review.

Several studies on the positive effects of additional roughage (i.e. not only straw) and increased space allowance are present in the literature. A high fibre diet have been shown to increase satiety in growing pigs (Kallabis and Kaufmann 2012), and pigs with access to additional roughage such as grass, clover, chicory, maize or whole crop silage had greater opportunity to perform species-specific behaviours. Research has proven higher activity levels, and more time spent on foraging and rooting behaviours among pigs that received these substrates, compared to those that only received straw (Høøk Presto et al. 2009; Jensen et al. 2010; Holinger et al. 2018a; Presto et al. 2013; Presto Åkerfeldt et al. 2019). Roughage also occupied the pigs for longer time, resulting in fewer wounds on their bodies from violent social interactions (Presto et al. 2013), less aggressive interactions with other pigs in the lying area and less behaviours directed towards pen fittings (Høøk Presto et al. 2009; Jensen et al. 2010; Presto Åkerfeldt et al. 2019). A higher space allowance modified the pigs' behaviour positively (Cornale et al. 2015) and influenced pigs to manipulate with the offered rooting material more often (Jensen et al. 2010). Additionally, the lower stocking density reduced the corticosteroid levels in pig faeces, which could indicate an improvement in welfare conditions (Cornale et al. 2015). Increased space allowance by outdoor rearing of heavyweight pigs increased their activity with a wider range of behaviours and was also found to lower the aggressions during preslaughter mixing, which further suggests improved welfare (Terlouw et al. 2009). Arroyo et al. (2019) showed that the neurophysiology of pigs was noticeably changed due to housing conditions (indoors vs. access to pasture) and road transport (high-stress vs. low-stress conditions), and it was suggested that animals raised partially outdoors respond differently (in a positive manner) to transport-related stress and can cope with new environments better than animals raised indoors. Outdoor areas with pasture increased the pigs' activity level and their time spent in the outdoor range. Higher activity, more foraging and rooting behaviours, as well as fewer social interactions and tail manipulations were found among outdoor-housed pigs compared to conventional indoorhoused pigs (Høøk Presto et al. 2008). Correspondingly, pigs with access to a pasture area spent $21 \%$ of their time there and less time inside the pig house and on the concrete outdoor area, compared with pigs without pasture (Botermans et al. 2015).

In organic production, it is common to keep loose housed sows in groups on larger areas during lactation. This allows the sows to leave the piglets for shorter periods. When piglets were separated from the sow for $8 \mathrm{~h}$ /day 1 week prior to weaning, piglet feed consumption and growth in the immediate post-weaning period were improved. In combination with comingling with another litter, it also increased the creep feed intake and reduced the aggression level after weaning (Turpin et al. 2017). Mixing of piglets during lactation was beneficial for piglets' social development, their adaptation to postweaning situations and post-weaning performance (van Nieuwamerongen et al. 2014, 2015; Verdon et al. 2016, 2019). In a study by Bohnenkamp et al. (2013), early mixing had no effect on piglet growth but reduced agonistic behaviour and lesion scores in the piglets 2 days after weaning. Piglets that were socialized during lactation were also more "sleepy/tired" or "content/relaxed" than un-socialized pigs which were more "active/ curious" or "aggressive/dominant". This suggests that the socializing that often occurs in organic systems may be beneficial from a welfare perspective of piglets (Morgan et al. 2014), but the time for mixing is essential in order not to adventure piglet health (Thomsson et al. 2016).

Laying hens and broiler chicken production

The main health challenges in organic laying hens have been found to be similar to those of loose housed laying hens indoor, as well as to free-range hens outdoor that are not managed according to the organic regulations (Hartcher and Jones 2017). The main areas of concern are injurious pecking (incl. feather pecking and cannibalism), internal and external parasites and possibilities to express species-specific behaviours. For organic broilers, the main health issues have been found to be 
foot pad dermatitis (FPD) and hock and breast lesions (van de Weerd et al. 2009). Van de Weerd et al. (2009) concluded that welfare problems are associated with suitability of breed, in particular in broilers, with nutritional challenges in relation to the banning of synthetic amino acids and also with range use and group size. They also found that there is a considerable variation in farming systems within the organic sector regarding farm size, housing and quality of the free-range area, capacity to produce home grown feed, opportunities for pasture rotation, etc., which influence the health and welfare conditions on individual farms.

Hygiene measures in houses and rotation of outdoor areas are important for all livestock species, specifically organic layers and broiler chickens that are exposed to wild birds that can transmit bird-specific or zoonotic diseases, e.g. avian influenza or salmonella. However, salmonella may not be as easily transmitted to freeranged birds as previous thought, due to preventive measures (e.g. continuous salmonella monitoring, heat treatment of feed and no feeding of birds outdoors), which are effective strategies, lowering the prevalence (Wierup et al. 2017). Furthermore, the risk of nematode infection is decreasing if the birds have more access to the range (Thapa et al. 2015).

\section{Metabolic/digestive disorders and productivity}

Increased mortality due to injury and disease is often found among organic hens (and other free-range hens) compared with laying hens housed in aviaries or in cages (Leenstra et al. 2014). In organic broiler systems, production is significantly decreased for similar reasons, and long rearing times have also been found to relate to high mortality in broiler chickens (Rezaei et al. 2018). For poultry, the ban on synthetic amino acids in organic systems reduces the yield potential of the conventional hybrids (Eriksson et al. 2009; Eriksson et al. 2010). Improved and well-balanced diets to raise yields can also improve animal welfare by, e.g. preventing injurious behaviour and avoiding nutrient deficiencies. For example, problems with feather or vent pecking in laying hens were reduced by feeding an optimal diet with high-quality protein and roughage allowances (Rodenburg et al. 2013).

The correspondence between farm production system and breed/genetic potential has been extensively covered by previous research. Although traditional breeds are used in organic flocks in some countries, e.g. Italy, the same fast-growing hybrids as in conventional broiler production, i.e. Ross or Cobb from crosses of Cornish and White Rock bird strains, have been used in, e.g. the Nordic countries. These fast-growing and highly efficient broilers reach market weight in 56 weeks (ROSS performance objective, 2019). Rearing these birds for the longer period that organic rules demand (i.e. $\geq 70$ days) increase mortality and culling rate due to severe leg weakness associated with their rapid growth (Eriksson et al. 2009). However, several factors have to be considered in the comparison of bird welfare when comparing organic and non-organic systems, such as housing conditions and genetics. Castellini et al. (2016) found that Ross chickens did not appear to be adapted to the organic system. They found that chickens with the highest daily weight gain had a negative linear correlation to adaptation to the system, whereas slowgrowing strains with intermediate growth results showed the best adaptability index, and this is similar to the findings in previous studies (Castellini et al. 2012; Castellini et al. 2016). In a study that synthesized data from the Netherlands, the UK and Italy, several aspects of animal welfare, as well as performance, were assessed. It was found that an intermediate system had higher welfare score than extensive outdoor or organic systems, although the conventional systems had lowest animal welfare score (Gocsik et al. 2016). Furthermore, in a Belgian study (Tuyttens et al. 2008), it was found that the welfare of slow-growing broiler chickens in organic farms was improved compared to the welfare of fast-growing hybrids in conventional farms. In particular the lameness and other leg problems were more frequent in broilers from conventional farms (Tuyttens et al. 2008).

Concerning feather conditions, slower growing hybrids showed the best values for all considered body regions, as well as the absolute absence of foot pad and breast blister lesions (Castellini et al. 2016). This was also confirmed by Skomorucha and Sosnowka-Czajka (2017), who found that Ross 308 chickens are probably the least suitable for rearing during summer production cycles, as these birds had low ability to adapt to warmer conditions.

\section{Lameness, foot pad dermatitis and other diseases}

Positive effects from free-range systems on foot and leg health are expected in layers, as well as in broiler chickens. However, there are no clear correlations 
demonstrated yet, as choice of bird strain as well as different slaughter ages of broilers in conventional and organic production is influencing the results. FPD is more common in conventional production than in organic broiler farms where housing conditions are different and the stocking density is lower. In a study by Gouveia et al. (2009), broiler welfare of birds in extensive indoor systems (EI) and traditional free-range systems (TFR) during rearing and preslaughter handling was assessed by measuring post mortem lesions. TFR birds exhibited the highest prevalence of bruises and lowest prevalence of FPD. Furthermore, the study showed that lesions were associated with other factors than production system, such as distance to abattoir and gender of the birds. In a Danish surveillance study of FPD at slaughter, as an indicator of on-farm broiler welfare, Lund et al. (2017) found less FPD among organic than conventional broilers. However, the results were inconsistent, and the authors considered that organic broiler were more difficult to score than conventional broilers, which might explain the inconsistency (Lund et al. 2017). Bergmann et al. (2016) found that shortly before slaughter, $2.5 \%$ of the organic broilers (day 40 ) and $16.8 \%$ of the conventional broilers (day 35) showed various degrees of FPD, although factors like farm and bird strain also had a significant effect on the occurrence of hyperkeratosis and FPD. Furthermore, the live body weight had a significant effect on the prevalence of hock burn in both strains. The authors found that obvious lameness $(0.8 \%)$ and immobility $(0.5 \%)$ was only identified in conventional broilers, and not in any birds in organic production. Outdoor access and low-nutrient diet also resulted in better gait score according to Fanatico et al. (2008).

According to Tahamtani et al. (2018), lameness was less prevalent and severe in Danish organic broiler systems relative to conventional production. In a recent Swedish study by Wilhelmsson et al. (2019), the same trend was found for lameness as well as for other clinical health problems including mortality rate, contact dermatitis and plumage cleanliness. Indications of poor welfare were observed in the slower-growing hybrid compared to a fast-growing hybrid but to a lesser extent and later during rearing (Wilhelmsson et al. 2019). Sarica et al. (2014) found that FPD scores varied significantly between genotypes, with higher scores found in fastgrowing chickens. Heavier birds and male birds were also found to have more problems, and chickens with outdoor access had higher FPD scores than those without outside access. In a study by Fanatico et al. (2008), it was found that genotype affected leg health, with slow-growing birds having better gait scores and less tibial dyschondroplasia. Free-range access may also have negative impacts by increased risk for diseases carried by wildlife, parasitic infections, predation and contact with soil contaminants (Newberry 2017). However, Wnuk-Gnich et al. (2016) found that broiler chickens having access to free ranging systems were characterized by a significantly lower mortality rate compared to the control birds. High levels of freerange use have been associated with a reduced incidence of keel bone fractures in laying hens (Richards et al. 2012; Jung et al. 2019). The literature search did not result in specific studies of the occurrence of erysipelas infections; thus, this was excluded in this review.

\section{Parasite infections}

Regarding internal parasites of organic poultry, helminths, such as gastrointestinal nematodes (GIN) and cestodes (tape worms), are mainly seen as a health and welfare problems in laying hens, whereas coccidiosis caused by Eimeria spp. is more prevalent in broiler chickens. In laying hens, the most important GIN are Ascaridia galli and Heterakis spp., and several studies have shown that free-range and loose-housed indoor flocks have higher numbers of $A$. galli eggs than caged flocks (Dao et al. 2019; Fossum et al. 2009; Jansson et al. 2010). In a British epidemiological study in farms with egg production in free-range areas outdoor, organic as well as non-organic, and with stationary as well as mobile houses, it was found that A. galli and Heterakis spp. were the most common intestinal parasites (Sherwin et al. 2013). However, they concluded that these infections were not severe as no negative effect on welfare indicators or production variables was found (Sherwin et al. 2013). Nevertheless, other studies have found that infection with A. galli and Heterakis spp. has been associated with increased mortality in organic egg production but may be reduced by control measures (Hinrichsen et al. 2016). In a trans-European study, Thapa et al. (2015) found that A. galli was highly prevalent across Europe (69.5\% of all flocks). Furthermore, they found that the prevalence of cestodes of Raillietina spp. was $13.6 \%$. The authors found, when analysing several management risk factors, that only pasture access time had a significant negative association with worm burden from A. galli. This was in 
contrast to the previous belief that outdoor access may increase the risk of helminth infections in production animals. Jansson et al. (2010) found no significant difference in prevalence of $A$. galli between hens kept on litter indoors and free-range/organic hens. Furthermore, they found that absence of a hygiene barrier at the entrance of the unit was a risk factor for increasing transmission of GIN. This suggests that parasite infection was introduced horizontally to the farms.

No publications of coccidiosis in organic broiler chickens comparing the situation to non-organic freerange broilers were found in this literature review according to the selection criteria. As paraphyletic treatment with coccidiostats is not allowed in organic production, the birds are exposed to infection. However, vaccination is commonly used, and the decreased stocking density in organic broiler production as well as the restricted group size may be favourable in reducing the contamination risk. The red mite (Dermanyssus gallinae) is the most important ectoparasite of laying hens in Europe, and it is more prevalent in non-caged layer flocks, than in caged flocks. As the parasite infestation is mainly depending on housing equipment and management of indoor areas, the infestation risk is not different in production system where the hens are either loose housed indoor (i.e. aviaries, barn systems or housed in organic or non-organic free-range systems with outdoor access).

\section{Behavioural effects}

In comparison with aviary systems with high stocking density, the increased space allowance and free-range access in organic egg production are meant to improve the welfare of laying hens by providing them possibilities to express their species-specific behaviour. This can result in a lower incidence of maladaptive behaviours like feather pecking and cannibalism, if the hens use the outdoor area, as reported in different studies (Bestman et al. 2017; Jung et al. 2019). The understanding of injurious pecking, however, still needs to be improved in order to fully prevent the problem. In a study by Yngvesson et al. (2017), 27\% of the slowgrowing broilers perched simultaneously at night, a very low proportion compared with, e.g. laying hens. The authors suggested that to ensure acceptable welfare and health in these broilers, it may be necessary to provide more opportunities for them to rest in an elevated position. Bozakova et al. (2011) found that higher welfare of birds reared organically was linked to the greater number of birds spending their time dust bathing and preening, fewer episodes of aggressive behaviours, as well as lower plasma corticosterone levels, compared to birds reared indoor on litter. In stress tests, it was found that slow-growing bird strains (more commonly used in organic production systems) displayed a quicker reaction time when submitted to tonic immobility test, which implies less stress reaction (Castellini et al. 2016). In the same study, they also observed a greater variety of the behaviour of slow-growing birds and that they exploited all the pasture area, compared with mediumslow and fast-growing birds.

\section{Discussion}

Impact on the systematic search on the outcome

Systematic reviews are important tools to summarize data correctly and reliably and should include a welldefined question that is quantitatively analysed. We aimed to describe the status of animal health and welfare in organic animal production. Therefore, the method of the current paper would be better described as a systematic mapping, based on a systematic search. Using the PIO approach, with the same search items in different search engines and in collaboration with a professional librarian specialized in scientific databases, gave a homogeneous and reliable search result for the different animal categories. However, the diverse and nonconsistent use of the word "organic" in the literature made the search very extensive in order to capture relevant publications, which was reflected in the large number of publications.

The included health and welfare indicators for the different animal categories aimed to reflect relevant health issues and behavioural effects and were selected based on current knowledge and previous research. The study, which was limited to the most important species in organic production, i.e. dairy and beef cattle, sheep, pig, laying hen and broiler chicken, had the starting point for the search period in year 2008. This point was set in order for comparison between systems under similar conditions reflected in more equivalent production practices, as the new commission regulation was implemented at that time. In accordance with the reviews by Hovi et al. (2003) and van Wagenberg et al. (2017), the present review also 
found that the included studies varied broadly due to different research criteria, variation in the number of farms and differences in farm production and conditions as well as management systems. This might have had an impact on the outcome. It was however not our intention to assess the methodological quality of the reviewed studies, but due to the descriptive nature of some literature, low sample size in some studies or lack of available data, it was not possible to compare the studies in the same domain and evaluate the benchmark appropriately.

Health status and behavioural effects in organic production

\section{Dairy cow, beef cattle and sheep production}

The outcome of this review indicates that the main health issues facing organic dairy farmers are basically similar to those reported on non-organic farms. However, it would be dangerous to rely on this body of evidence alone, given the almost certain differences in reporting health and treatments from organic and nonorganic farms (Sutherland et al. 2013). There is no apparent simple relationship between single factors and the prevalence of mastitis in dairy cows and sheep in the organic context. However, genetic factors, production type, management and hygienic farming practices are reported as risk factors (EFSA 2014; Casao et al. 2017). Various studies performed in several European countries have shown that current udder health levels implicate necessary improvement in organic dairy farms (Ivemeyer et al. 2012; Krieger et al. 2017). Lamb mortality is an important welfare issue although there is little evidence of its relation to specific factors in an organic context. The literature indicates that organic management can reduce lameness in dairy cow and sheep herds. The prevalence of lameness is on the other hand significantly influenced by numerous factors, and the combination of management practices, including grazing requirements that are combined with different types of housing, will determine the foot and leg health conditions (Pinedo et al. 2017). Obvious lameness indicates that the animal has severe pain. Gait assessment could be used as an indirect measure of foot disease, thus representing a valid welfare parameter (Napolitano et al. 2009), and recording of the prevalence of hock lesions and footbath should be used in order to keep the disease load low. Parasitism by GIN is regarded to be one of the biggest health problems in organic lamb production although there seems to be a large variation in parasite load on an individual level as well as between farms. In order to lower the prevalence, different alternative measures to control GIN is recommended (Burke et al. 2012), combined with breeding for resistance (Hooper et al. 2014; Chevrotiere et al. 2011; Burke et al. 2012; Williams 2011). There is a welldocumented genetic variation in resistance to GIN, and breeding for developing genetically resistant sheep is a promising strategy (Mederos et al. 2012).

The effects of roughage, larger areas and outdoor access on the behaviour pattern among organic dairy cows and sheep are according to the findings of this review, not that pronounced. This is probably due to smaller differences in the appliance of these systems, compared with those of monogastric animals, as both organic and conventional dairy cow and sheep production systems, grazing and forage-based feeding are common. Although some publication have found positive effects on behaviour, due to factors such as larger areas and longer outdoor periods, this review could not show clear evidence of a positive health and welfare effect, on, e.g. organic than on non-organic sheep farms (Gray 2008; Napolitano et al. 2009). The same situation seems to be the case in organic dairy farms, where the welfare status has been shown to be at a similar level as in conventional dairy farms (Bergman et al. 2014). However, in comparison with feedlot systems, where, e.g. lambs are fattened with large amounts of concentrates in crowded pens and barren environments, health and welfare problems however seem less probable to develop in organic production. In spite of differences in pasture use, feeds and feed additives, breed and age distribution and reproductive management across farms and production systems, it is suggested that lack of behavioural welfare benefits relate to housing and thereby could be improved by management practices (Langford et al. 2011).

\section{Pig, laying hen and broiler production}

Piglet mortality due to the crushing of piglets and inadequate nursing of group-housed piglets are still the most frequently reported causes of death across organic production systems (Lindgren et al. 2013; Westin et al. 2015). Large litters, especially in sows with higher parity number, and farrowing system (loose housing and group housing with free farrowing) are the major 
risks for stillbirth (Rangstrup-Christensen et al. 2017, 2018a, b) and crushing of piglets (Hales et al. 2014, 2015; Grimberg-Henrici et al. 2019). The primary reason to use farrowing crates is piglet survival. The crates do however prevent sows from moving freely and interacting unrestrictedly with their piglets and are therefore banned in organic production. In the context of animal health, and the opportunity for animals to live a natural life according to their physiological and behavioural conditions and well-being, the organic sector is facing a clear goal conflict within this area. Osteochondrosis may represent a larger health and animal welfare problem in organic outdoor and freerange pig production than previously assumed. Although exercise might help to strengthen the joint supportive tissues, the literature review indicates that pig leg health is challenged during rearing in environments with large space allowances and outdoor access and point at the importance of preventing and monitoring leg health in such production systems (Etterlin et al. 2014, 2015; Wallenbeck et al. 2020). Parasite infections and respiratory diseases do not seem to differ considerably either between organic and conventional production or different housing systems within organic production according to the literature. As organic farming in recent years is facing new indoor-based housing environments, this might be one causative factor to the results.

Organic egg production is predominantly challenged by health and welfare problems related to injurious feather pecking and cannibalism, as well as internal and external parasites, and the possibilities for birds to express their species-specific behaviours. There are studies highlighting higher mortality related to the production system (e.g. organic and free range), but the reviewed data demonstrates that the health and welfare challenges are the same as those in non-organic systems, independently of indoor or (non-organic) outdoor freerange systems (Hartcher and Jones 2017). For organic broilers, identified and relevant health parameters that need improvement are dermatitis of footpads, hocks and breasts. The welfare problems among organic broiler chickens have a clear connection to the suitability of breed, with nutritional challenges, metabolic disorders and leg problems related to the banning of synthetic amino acids, use of outdoor areas and group size (van de Weerd et al. 2009). The high incidences of mortality due to lameness and circulatory problems reported for birds of fast-growing breeds reared in organic production systems with long rearing periods further reduce the net yield (Wallenbeck et al. 2017; Rezaei et al. 2018). If future organic regulations were to allow supplementation of essential amino acids in livestock diets, that would be a major advantage, allowing avoidance of nutrient leakage caused by overfeeding (Eriksson et al. 2010; Leenstra et al. 2014). As an alternative to fast-growing hybrids, slower-growing genotypes could be more suitable for production systems with longer rearing periods. Additional scientific information about the effect of low-protein diets on growth patterns for slow-, medium- and fast-growing genotypes to that of Fanatico et al. (2005) are needed.

Access to additional roughage, high fibre diets, increased space allowance and outdoor and free-range access enables better opportunities for animals to perform species-specific behaviours and live a natural life and are therefore included as legislative rules. The literature reviewed clearly demonstrates that these elements have positive effects on the behaviour of organic pigs and poultry. The findings are not surprising, as these organic production systems differ substantially from the praxis in non-organic pig, layer and broiler production systems. Moreover, keeping sows in loose housed farrowing systems enhances sow behaviour and allows for improvements in post-weaning piglet feed consumption and growth. Among organic layers, the incidence of harmful behaviours, such as feather pecking and cannibalism, can be reduced when hens are reared in lower stocking densities and are offered free-range areas (Bestman et al. 2017; Jung et al. 2019). The use of slower-growing breeds in broiler production is a prerequisite for the longer rearing time and adaptation to the production system. It is a major impact for improved animal health at the flock level, due to more appropriate behaviour and is important, as it also will increase the number of broilers being healthy at slaughter compared with fast-growing breeds (Rezaei et al. 2018; Wallenbeck et al. 2017).

Impact of the outcome in the context of the organic values

The current mapping indicates that varying results and inconsistent interpretations within the area of health and welfare in organic production still occur, which is in accordance with previous reviews (Hovi et al. 2003; Sundrum et al. 2010; van Wagenberg et al. 2017). Several publications reviewed in the present study 
address factors related to housing and management that negatively influence animal health but, on the contrary, have a positive effect on animal behaviour. A multifunctional farming system according to the fundamental organic principles might cause the system as such to imply conflicts interacting with animal health and welfare of the individual animal, e.g. leg health or parasite burden of free-ranging animals. Although sick animals should be treated with appropriate therapy, organic farmers are encouraged to use preventive measures to lower, e.g. the pathogen load, in order to eliminate future morbidity (IFOAM 2005). This conflict may be a causative factor to the criticism about animal welfare in organic production. Along with the development of organic animal husbandry, the risks for goal conflicts and practical implications, not foreseen when the legislative rules were developed, arises when farmers put the rules into practice.

Organic production aims for less intensive animal production, which generally means that the animals have access to a more spacious and enriched environment, access to an outdoor range as well as restricted group sizes (EC 2008). On the contrary, the organic sector has experienced an increased intensification in recent years due to economic reasons for the individual farm. Moreover, defined as a production method by minimum standards, doubts have arisen whether organic animal husbandry can be characterized in dissociation to or even achieve better than conventional animal husbandry systems do regarding animal health and welfare (Sundrum et al. 2010; Sutherland et al. 2013). Despite legally and well-defined basic rules of organic production, a broad diversity of production systems occurs, including large-scale production systems with a higher number of animals per farm. The rising demand for productivity and profitability among farmers, with, e.g. continued breeding for high growth rates, without taking other important breeding traits such as animal health and behaviour into account, and the use of modern high producing breeds, often selected for conventional production environments, in organic production might risk aggravating current health problems further (Röös et al. 2018).

Due to legislative rules, organic farmers (except in poultry) are more likely to keep the number of purchased animals low and, if they buy animals, these are kept in quarantine (Toma et al. 2013). This could be a potential risk for animals being kept longer in production, with impaired health as a result. Animals' ability to live a natural life and perform species-specific behaviours is regarded as a prerequisite for good animal welfare; however, the combination of organic management practices with different types of housing results in characteristics that will affect animals' health condition (Pinedo et al. 2017). Moreover, genotype $\times$ environment interactions indicate that modern high-producing breeds of pigs might not always be the best suited in an organic environment, e.g. outdoor areas, although it seems that the problems are less for high-producing laying hens and dairy cows (Wallenbeck et al. 2009b; Sundberg et al. 2010). Although health-related traits are included in selection indexes for livestock, inclusion of functional robustness traits will be important (Oltenacu and Broom 2010). For further improvement, the inclusion of, e.g. behavioural traits (Turner 2011) and non-market values, such as ethical values or environmental impact (Olesen et al. 2000) should be considered. Despite the counteracting relationship between robustness and production traits, a positive genetic trend in both could be achieved when they are appropriately included in breeding goals and selection criteria (Knap 2009). For this, improved identification of farm-specific factors and outcome-oriented animal health and welfare indicators is a prerequisite, and policy options with potential for securing a low prevalence of production diseases on organic farms need to be highlighted.

The outcome of the current mapping supports the fact that the health status of organic dairy cow, beef cattle, sheep, pig, laying hen and broiler chickens in general is good, in relation to the definition and guiding principles of animal health and welfare stipulated by the World Organisation for Animal Health (OIE 2019). In accordance with Sundrum (2001), the findings indicate that the minimum standards of organic farming seem to provide a basis for good living conditions of farm animals but appear to be insufficient to ensure a higher animal health status than in conventional livestock farming. In the context of the fundamental ideas of organic farming and animal welfare, where natural living and animals' emotional states play important parts (IFOAM 2005), the positive behavioural effects found in this review indicate that the organic standards offer a good framework for high animal welfare management.

Although organic production meets the needs of positive welfare and naturalness, the systems are still facing several challenges, in particular related to animal health. The outcomes from this review support the conclusions by Hovi et al. (2003) that there is a need 
of progression regarding apparent goal conflicts that arise between the fundamental principles of organic farming and animal health and welfare due to management and practical implications. In an era that is turning from minimizing animal suffering towards focusing on positive animal welfare, it is recognized that the current reference standards in animal welfare science, an emerging field of research, requires the presence of positive experiences, as well as the absence of negative.

\section{Conclusions}

The welfare status of organic dairy cow, beef cattle, sheep, pig, laying hen and broiler chickens, in general, is good, in relation to the definition and guiding principles of animal health and welfare. Although there are some areas with health and welfare advantages in organic livestock production systems, some still require improvements, and there is no strong evidence supporting that animal health and welfare are neither inferior nor distinctly better, in organic compared with conventional production systems according to the literature we explored. Mastitis in organic dairy and sheep farms, high mortality rates of lambs, piglets and broiler chickens, high parasite load and infestation, as well as hoof and leg problems among all animal species are relevant health issues that need improvement. Prevalence of diseases is mainly related to management practices, grazing and housing systems; therefore, possibilities to monitor health are important factors determining animal health conditions.

The possibilities for animals to perform speciesspecific behaviours seem to be better met by the organic regulation, which indicates that the organic standards offer a good framework for good animal welfare management, even though they appear to be insufficient to ensure a higher animal health status than in conventional livestock farming. In order to consider and guarantee health-related aspects of animal welfare, outcome-based assessments should be implemented in organic standards.

Acknowledgements The authors would like to thank the Centre for Organic Food \& Farming, EPOK, for contributing financial support for performing this review paper. Further, we want to acknowledge Agneta Lindsten, professional librarian at the SLU University Library, for helping with defining search terms and with the selection procedure in the systematic search of literature. The authors would also acknowledge special thanks to Professor
Johan Höglund at the Department of Biomedical Sciences and Veterinary Public Health, SLU, and Associate Professor Anna Wallenbeck at the Department of Animal Health and Environment, SLU, for reviewing parts of this literature review.

Funding Open access funding provided by Swedish University of Agricultural Sciences.

Open Access This article is licensed under a Creative Commons Attribution 4.0 International License, which permits use, sharing, adaptation, distribution and reproduction in any medium or format, as long as you give appropriate credit to the original author(s) and the source, provide a link to the Creative Commons licence, and indicate if changes were made. The images or other third party material in this article are included in the article's Creative Commons licence, unless indicated otherwise in a credit line to the material. If material is not included in the article's Creative Commons licence and your intended use is not permitted by statutory regulation or exceeds the permitted use, you will need to obtain permission directly from the copyright holder. To view a copy of this licence, visit http://creativecommons. org/licenses/by/4.0/.

\section{References}

Alban L, Petersen JV, Busch ME (2015) A comparison between lesions found during meat inspection of finishing pigs raised under organic/free-range conditions and conventional, indoor conditions. Porc Health Manag 1:4. https://doi.org/10.1186 /2055-5660-1-4

Arroyo L, Valent D, Carreras R, Pena R, Sabria J, Velarde A, Bassols A (2019) Housing and road transport modify the brain neurotransmitter systems of pigs: do pigs raised in different conditions cope differently with unknown environments? PLoS One 14(1):e0210406. https://doi.org/10.1371 /journal.pone.0210406

Astorga RJ, Gomez Laguna J, Hernandez Garcia M, Echeita Sarrionandia A, Quiros Carmona S, Luque Moreno I, Gibert EC (2010) Surveillance on Salmonella prevalence in Iberian pigs raised in free-range system. AGRIS Agricultural Science and Technology Information No 64:26-33 http://agris.fao.org/agris-search/search.do?recordID= ES2010000405

Barker ZE, Leach KA, Whay HR, Bell NJ, Main DCJ (2010) Assessment of lameness prevalence and associated risk factors in dairy herds in England and Wales. J Dairy Sci 93:932941

Bartussek H, Leeb CH and Held S (2000) Animal need index for cattle ANI 35 L/2000, cattle. Federal Research Institute for Agriculture in Alpine Regions BAL pp 1-20. Gumpenstein 8952: Irdning, Austria

Bennedsgaard TW, Klaas IC, Vaarst M (2010) Reducing use of antimicrobials - experiences from an intervention study in organic dairy herds in Denmark. Livest Sci 131(2-3):183192. https://doi.org/10.1016/j.livsci.2010.03.018

Benoit M, Tournadre H, Dulph JP, Laignel G, Prache S, Cabaret J (2009) Is intensification of reproduction rhythm sustainable in an organic sheep production system? A 4-year 
interdisciplinary study. Animal 3(5):753-763. https://doi. org $/ 10.1017 / \mathrm{s} 1751731109004133$

Bergman MA, Richert RM, Cicconi-Hogan KM, Gamroth MJ, Schukken YH, Stiglbauer KE, Ruegg PL (2014) Comparison of selected animal observations and management practices used to assess welfare of calves and adult dairy cows on organic and conventional dairy farms. J Dairy Sci 97(7): 4269-4280. https://doi.org/10.3168/jds.2013-7766

Bergmann S, Louton H, Westermaier C, Wilutzky K, Bender A, Bachmeier J, Erhard MH, Rauch E (2016) Field trial on animal-based measures for animal welfare in slow growing broilers reared under an alternative concept suitable for the German market. Berliner Und Munchener Tierarztliche Wochenschrift 129(11):453-461. https://doi.org/10.2376 /0005-9366-16035

Bestman M, Verwer C, Brenninkmeyer C, Willett A, Hinrichsen LK, Smajlhodzic F, Heerkens JLT, Gunnarsson S, Ferrante V (2017) Feather-pecking and injurious pecking in organic laying hens in 107 flocks from eight European countries. Anim Welf 26(3):355-363. https://doi.org/10.7120 /09627286.26.3.355

Blanco-Penedo I, Lopez-Alonso M, Miranda M, Castillo C, Hernandez J, Prieto Montana F, Benedito JL, Harapin I, Kos J (2008) Metabolic profile determination in calves from different management in NW Spain. University of Zagreb, Faculty of Veterinary Medicine, Zagreb, Croatia

Blanco-Penedo I, Shore RF, Miranda M, Benedito JL, LópezAlonso M (2009) Factors affecting trace element status in calves in NW Spain. Livest Sci 123(2-3):198-208

Blanco-Penedo I, Fall N, Emanuelson U (2012a) Effects of turning to $100 \%$ organic feed on metabolic status of Swedish organic dairy cows. Livest Sci 143(2):242-248. https://doi. org/10.1016/j.livsci.2011.09.023

Blanco-Penedo I, Lopez-Alonso M, Shore RF, Miranda M, Castillo C, Hernandez J, Benedito JL (2012b) Evaluation of organic, conventional and intensive beef farm systems: health, management and animal production. Animal 6(9): 1503-1511. https://doi.org/10.1017/S1751731112000298

Blanco-Penedo I, Lundh T, Holtenius K, Fall N, Emanuelson U (2014) The status of essential elements and associations with milk yield and the occurrence of mastitis in organic and conventional dairy herds. Livest Sci 168:120-127. https://doi.org/10.1016/j.livsci.2014.07.016

Bohnenkamp AL, Traulsen I, Meyer C, Muller K, Krieter J (2013) Comparison of growth performance and agonistic interaction in weaned piglets of different weight classes from farrowing systems with group or single housing. Animal 7(2):309-315. https://doi.org/10.1017/s1751731112001541

Botermans JAM, Olsson AC, Andersson M, Bergsten C, Svendsen J (2015) Performance, health and behaviour of organic growing-finishing pigs in two different housing systems with or without access to pasture. Acta Agr Scand A-An 65 (3): 158-167. https://doi.org/10.1080 /09064702.2016.1158308

Bozakova N, Gerzilov V, Popova-Ralcheva S, Sredkova V (2011) Welfare assessment of three chicken breeds (Gallus gallus domesticus) under different production. Biotechn Anim Husb 27(4):1705-1713

Brenninkmeyer C, Dippel S, Brinkmann J, March S, Winckler C, Knierim U (2016) Investigating integument alterations in cubicle housed dairy cows: which types and locations can be combined? Animal 10:342-348. https://doi.org/10.1017 /S1751731115001032

Burke JM, Miller JE, Mosjidis JA, Terrill TH (2012) Grazing sericea lespedeza for control of gastrointestinal nematodes in lambs. Vet Parasitol 186(3-4):507-512. https://doi. org/10.1016/j.vetpar.2011.12.004

Cabaret J, Nicourt C (2009) Sanitary problems in organic farming: facts, conceptions and practices. Prod Anim 22(3):235-243

Cabaret J, Benoit M, Laignel G, Nicourt C (2011) Health advisors in organic meet sheep farms: the role of the veterinarians. Open Veterinary Science Journal 5 (Special Issue \#001):711. doi:https://doi.org/10.2174/1874318801105010007

Caroprese M (2008) Sheep housing and welfare. Small Ruminant Res 76(1):21-25

Casao A, Maria GA, Abecia JA (2017) A preliminary study of the effects of organic farming on oocyte quality in ewe lambs. Zygote 25(1):98-102. https://doi.org/10.1017 /s0967199416000393

Castellini C, Boggia A, Cortina C, Dal Bosco A, Paolotti L, Novelli E, Mugnai C (2012) A multicriteria approach for measuring the sustainability of different poultry production systems. J Clean Prod 37:192-201. https://doi.org/10.1016/j. jclepro.2012.07.006

Castellini C, Mugnai C, Moscati L, Mattioli S, Amato MG, Mancinelli AC, Ad B (2016) Adaptation to organic rearing system of eight different chicken genotypes: behaviour, welfare and performance. Ital J Anim Sci 15(1):37-46. https://doi.org/10.1080/1828051x.2015.1131893

Centoducati P, Maggiolino A, De Palo P, Milella P, Tateo A (2015) Semiextensively reared lactating ewes: effect of season and space allowance reduction on behavioral, productive, and hematologic parameters. J Vet Behav 10(1):73-77. https://doi.org/10.1016/j.jveb.2014.11.002

Charlier J, Sanders M, Vercruysse J (2009) The direct costs of infections with gastrointestinal nematodes and liver fluke in the Flemish dairy population. Vlaams Diergen Tijds 78:196200

Chevrotiere CDL, Moreno C, Jaquiet P, Mandonnet N (2011) Selection tools for the control of gastrointestinal parasitism in small ruminants. La selection genetique pour la maitrise des strongyloses gastro-intestinales des petits ruminants. Inra Prod Anim 24(3):221-234

Cornale P, Macchi E, Miretti S, Renna M, Lussiana C, Perona G, Mimosi A (2015) Effects of stocking density and environmental enrichment on behavior and fecal corticosteroid levels of pigs under commercial farm conditions. J Vet Behav 10(6):569-576. https://doi.org/10.1016/j.jveb.2015.05.002

Dao HT, Hunt PW, Sharma N, Swick RA, Barzegar S, Hine B, McNally J, Ruhnke I (2019) Analysis of antibody levels in egg yolk for detection of exposure to Ascaridia galli parasites in commercial laying hens. Poult Sci 98(1):179-187. https://doi.org/10.3382/ps/pey383

Darnhofer I, Lindenthal T, Bartel-Kratochvil R, Zollitsch W (2010) Conventionalisation of organic farming practices: from structural criteria towards an assessment based on organic principles. A review Agron Sustain Dev 30(1):67-81. https://doi.org/10.1051/agro/2009011

Dickins A, Clark CCA, Kaler J, Ferguson E, O'Kane H, Green LE (2016) Factors associated with the presence and prevalence of contagious ovine digital dermatitis: a 2013 study of 1136 
random English sheep flocks. Prev Vet Med 130:86-93. https://doi.org/10.1016/j.prevetmed.2016.06.009

Dippel S, Dolezal M, Brenninkmeyer C, Brinkmann J, March S, Knierim U, Winckler C (2009) Risk factors for lameness in freestall-housed dairy cows across two breeds, farming systems, and countries. J Dairy Sci 92(11):5476-5486. https://doi.org/10.3168/jds.2009-2288

Dippel S, Leeb C, Bochicchio D, Bonde M, Dietze K, Gunnarsson S, Lindgren K, Sundrum A, Wiberg S, Winckler C, Prunier A (2014) Health and welfare of organic pigs in Europe assessed with animal-based parameters. Org Agric 4(2):149-161. https://doi.org/10.1007/s13165-013-0041-3

Duval JE, Bareille N, Fourichon C, Madouasse A, Vaarst M (2016) Prev Med 133:10-21. https://doi.org/10.1016/j. prevetmed.2016.09.008

EC (2008) Commission Regulation (EC) No 889/2008 of 5 September 2008 laying down detailed rules for the implementation of Council Regulation (EC) No 834/2007 on organic production and labelling of organic products with regard to organic production, labelling and control

EFSA (2012) Panel on Animal Health and Welfare. Statement on the use of animal-based measures to assess the welfare of animals. EFSA Journal 10(6), 344. https://doi.org/10.2903/j. efsa.2012.2767

EFSA (2014) Scientific opinion on the welfare risks related to the farming of sheep for wool, meat and milk production. EFSA J 12(12):3933

Ellis KA, Jackson A, Bexiga R, Matthews J, McGoldrick J, Gilleard J, Forbes AB (2011) Use of diagnostic markers to monitor fasciolosis and gastrointestinal nematodes on an organic dairy farm. Vet Rec 169(20). https://doi. org/10.1136/vr.d5021

Eriksson M, Waldenstedt L, Engstrom B, Elwinger K (2009) Protein supply in organic broiler diets. Acta Agr Scand AAn 59(4):211-219. https://doi.org/10.1080 /09064700903358256

Eriksson M, Waldenstedt L, Elwinger K, Engström B, Fossum O (2010) Behaviour, production and health of organically reared fast-growing broilers fed low crude protein diets including different amino acid contents at start. Acta Agr Scand A-An 60(2):112-124. https://doi.org/10.1080 /09064702.2010.502243

Etterlin PE, Ytrehus B, Lundeheim N, Heldmer E, Osterberg J, Ekman S (2014) Effects of free-range and confined housing on joint health in a herd of fattening pigs BMC Vet Res 10 . doi:https://doi.org/10.1186/s12917-014-0208-5

Etterlin PE, Morrison DA, Osterberg J, Ytrehus B, Heldmer E, Ekman S (2015) Osteochondrosis, but not lameness, is more frequent among free-range pigs than confined herd-mates. Acta Vet Scand 57:10. https://doi.org/10.1186/s13028-0150154-7

EU (2018) Commission Regulation (EU) No 2018/848 of 30 May 2018 on organic production and labelling of organic products and repealing Council Regulation (EC) No 834/ 2007

Fanatico AC, Pillai PB, Cavitt LC, Owens CM, Emmert JL (2005) Evaluation of slower-growing broiler genotypes grown with and without outdoor access: Growth performance and carcass yield. Poult. Sci. 84:1321-1327. https://doi.org/10.1093 $/ \mathrm{ps} / 84.8 .1321$
Fanatico AC, Pillai PB, Hester PY, Falcone C, Mench JA, Owens CM, Emmert JL (2008) Performance, livability, and carcass yield of slow- and fast-growing chicken genotypes fed lownutrient or standard diets and raised indoors or with outdoor access. Poult Sci 87(6):1012-1021. https://doi.org/10.3382 /ps.2006-00424

Flaten O, Lien G (2009) Organic dairy farming in Norway under the $100 \%$ organically produced feed requirement. Livest Sci 126(1):28-37. https://doi.org/10.1016/j.livsci.2009.05.014

Fossum O, Jansson DS, Etterlin PE, Vagsholm I (2009) Causes of mortality in laying hens in different housing systems in 2001 to 2004. Acta Vet Scand 51:3. https://doi.org/10.1186/17510147-51-3

Früh B, Bochicchio D, Edwards S, Hegelund L, Leeb C, Sundrum A, Werne S, Wiberg S, Prunier A (2014) Description of organic pig production in Europe. Org Agric 4(2):83-92. https://doi.org/10.1007/s13165-013-0056-9

Gareis M, Oberlander S, Zipplies J, Reese S, Schade B, Bohm B, Schwaiger K (2016) Prevalence of auxiliary bursae and injuries of claws in fattening pigs at time of slaughter-results of a study at four slaughterhouses. Berl Münch Tierärztl Wochenschr. https://doi.org/10.2376/0005-9366-16032

Garmo RT, Waage S, Sviland S, Henriksen BIF, Østerås O, Reksen O (2010) Reproductive performance, udder health and antibiotic resistance in mastitis bacteria isolated from Norwegian Red cows in conventional and organic farming. Acta Vet Scand 52:11. https://doi.org/10.1186/1751-014752-11

Gocsik É, Brooshooft SD, de Jong IC, Saatkamp HW (2016) Costefficiency of animal welfare in broiler production systems: a pilot study using the Welfare Quality® assessment protocol. Agric Syst 146:55-69. https://doi.org/10.1016/j. agsy.2016.04.001

Gosling RJ, Mueller-Doblies D, Martelli F, Nunez-Garcia J, Kell N, Rabie A, Wales AD, Davies RH (2018) Observations on the distribution and persistence of monophasic Salmonella Typhimurium on infected pig and cattle farms. Vet Microbiol 227:90-96. https://doi.org/10.1016/j.vetmic.2018.10.032

Gouveia KG, Vaz-Pires P, da Costa PM (2009) Welfare assessment of broilers through examination of haematomas, footpad dermatitis, scratches and breast blisters at processing. Anim Welf 18(1):43-48

Gray D (2008) Organic sheep production: health problems and their management. Practice 30(2):78-84

Grimberg-Henrici CGE, Buttner K, Lohmeier RY, Burfeind O, Krieter J (2019) The effect of group-housing with freefarrowing pens on reproductive traits and the behaviour of low-risk and high-risk crushing sows. Appl Anim Behav Sci 211:33-40. https://doi.org/10.1016/j.applanim.2018.12.001

Gunnarsson S (2006) The conceptualisation of health and disease in veterinary medicine. Acta Vet Scand 48(20):1-6. https://doi.org/10.1186/1751-0147-48-20

Hales J, Moustsen VA, Nielsen MBF, Hansen CF (2014) Higher preweaning mortality in free farrowing pens compared with farrowing crates in three commercial pig farms. Animal 8(1): 113-120. https://doi.org/10.1017/s1751731113001869

Hales J, Moustsen VA, Nielsen MBF, Hansen CF (2015) Temporary confinement of loose-housed hyperprolific sows reduces piglet mortality. J Anim Sci 93(8):4079-4088. https://doi.org/10.2527/jas.2015-8973 
Hansen I (2015) Behavioural indicators of sheep and goat welfare in organic and conventional Norwegian farms. Acta Agr Scand A-An 65(1):55-61. https://doi.org/10.1080 /09064702.2015.1050447

Hartcher KM, Jones B (2017) The welfare of layer hens in cage and cage-free housing systems. Worlds Poult Sci 73(4):767781. https://doi.org/10.1017/S0043933917000812

Hinrichsen LK, Labouriau R, Engberg RM, Knierim U, Sorensen JT (2016) Helminth infection is associated with hen mortality in Danish organic egg production. Vet Rec 179(8):4. https://doi.org/10.1136/vr.103614

Höglund J, Dahlstrom F, Engstrom A, Hessle A, Jakubek EB, Schnieder T, Strube C, Sollenberg S (2010) Antibodies to major pasture borne helminth infections in bulk-tank milk samples from organic and nearby conventional dairy herds in south-central Sweden. Vet Parasitol 171(3):293-299. https://doi.org/10.1016/j.vetpar.2010.04.002

Höglund J, Elmahalawy ST, Halvarsson P, Gustafsson K (2019) Detection of Haemonchus contortus on sheep farms increases using an enhanced sampling protocol combined with PCR based diagnostics. Vet Parasitol X 2:100018. https://doi. org/10.1016/j.vpoa.2019.100018

Holinger M, Früh B, Stoll P, Graage R, Wirth S, Bruckmaier R, Prunier A, Kreuzer M, Hillmann E (2018a) Chronic intermittent stress exposure and access to grass silage interact differently in their effect on behaviour, gastric health and stress physiology of entire or castrated male growing-finishing pigs. Physiol Behav 195:58-68. https://doi.org/10.1016/j. physbeh.2018.07.019

Holinger M, Früh B, Stoll P, Kreuzer M, Hillmann E (2018b) Grass silage for growing-finishing pigs in addition to straw bedding: effects on behaviour and gastric health. Livest Sci 218:50-57. https://doi.org/10.1016/j.livsci.2018.10.012

Hoogenboom LAP, Bokhorst JG, Northolt MD, de Vijver L, Broex NJG, Mevius DJ, Meijs JAC, Van der Roest J (2008) Contaminants and microorganisms in Dutch organic food products: a comparison with conventional products. Food Addit Contam Part A-Chem 25(10):1195-1207. https://doi.org/10.1080/02652030802014930

Høøk Presto M, Andersson HK, Folestam S, Lindberg JE (2008) Activity behaviour and social interactions of pigs raised outdoors and indoors. Archiv Fur Tierzucht-Arch Anim Breed 51(4):338-350

Høøk Presto M, Algers B, Persson E, Andersson HK (2009) Different roughages to organic growing/finishing pigs - influence on activity behaviour and social interactions. Livest Sci 123(1):55-62. https://doi.org/10.1016/j. livsci.2008.10.007

Hooper KJ, Bobe G, Vorachek WR, Bishop-Stewart JK, Mosher WD, Pirelli GJ, Kent ML, Hall JA (2014) Effect of selenium yeast supplementation on naturally acquired parasitic infection in ewes. Biol Trace Elem Res 161(3):308-317. https://doi.org/10.1007/s12011-014-0134-1

Hovi M, Sundrum A, Thamsborg SM (2003) Animal health and welfare in organic livestock production in Europe: current state and future challenges. Livest Prod Sci 80(1-2):41-53. https://doi.org/10.1016/S0301-6226(02)00320-2

IFOAM (2005) Principles of organic agriculture. Available on https://wwwifoambio/sites/default/files/poa_english_webpdf 2020-03-06
Ivemeyer S, Smolders G, Brinkmann J, Gratzer E, Hansen B, Henriksen BIF, Hube J, Leeb C, March S, Mejdell C, Nicholas P, Roderick S, Stoger E, Vaarst M, Whistance LK, Winckler C, Walkenhorst M (2012) Impact of animal health and welfare planning on medicine use, herd health and production in European organic dairy farms. Livest Sci 145(1):63-72. https://doi.org/10.1016/j.livsci.2011.12.023

Jansson DS, Nyman A, Vagsholm I, Christensson D, Goransson M, Fossum O, Hoglund J (2010) Ascarid infections in laying hens kept in different housing systems. Avian Pathol 39(6): 525-532. https://doi.org/10.1080/03079457.2010.527923

Jensen MB, Studnitz M, Pedersen LJ (2010) The effect of type of rooting material and space allowance on exploration and abnormal behaviour in growing pigs. Appl Anim Behav Sci 123 (3):87-92. https://doi.org/10.1016/j. applanim.2010.01.002

Jung L, Niebuhr K, Hinrichsen LK, Gunnarsson S, Brenninkmeyer C, Bestman M, Heerkens J, Ferrari P, Knierim U (2019) Possible risk factors for keel bone damage in organic laying hens. Animal 13(10):2356-2364. https://doi.org/10.1017/S175173111900003X

Kallabis KE, Kaufmann O (2012) Effect of a high-fibre diet on the feeding behaviour of fattening pigs. Archiv Fur TierzuchtArch Anim Breed 55(3):272-284

Kantzoura V, Kouam MK, Theodoropoulou H, Feidas H, Theodoropoulos G (2012) Prevalence and risk factors of gastrointestinal parasitic infections in small ruminants in the Greek temperate Mediterranean environment. Open Journal of Vet Med 2(1):25-33

Kantzoura V, Diakou A, Kouam MK, Feidas H, Theodoropoulou $H$, Theodoropoulos G (2013) Seroprevalence and risk factors associated with zoonotic parasitic infections in small ruminants in the Greek temperate environment. Parasitol Intern 62(6):554-560

Katakam KK, Thamsborg SM, Dalsgaard A, Kyvsgaard NC, Mejer H (2016) Environmental contamination and transmission of Ascaris suum in Danish organic pig farms. Parasites Vectors 9:12. https://doi.org/10.1186/s13071-016-1349-0

Keessen EC, van den Berkt AJ, Haasjes NH, Hermanus C, Kuijper EJ, Lipman LJA (2011) The relation between farm specific factors and prevalence of Clostridium difficile in slaughter pigs. Vet Microbiol 154(1-2):130-134. https://doi. org/10.1016/j.vetmic.2011.06.032

Kern G, Traulsen I, Kemper N, Krieter J (2013) Analysis of somatic cell counts and risk factors associated with occurrence of bacteria in ewes of different primary purposes. Livest Sci 157(2-3):597-604. https://doi.org/10.1016/j. livsci.2013.09.008

Kern G, Traulsen I, Stamer E, Kemper N, Krieter J (2014) Effects and risk factors influencing longevity and animal health in sheep on organic farms: development of preventive measures. Zuchtungskunde 86(4):260-273

Kirchner MK, Ferris C, Abecia L, Yanez-Ruiz DR, Pop S, Voicu I, Dragomir C, Winckler C (2014) Welfare state of dairy cows in three European low-input and organic systems. Org Agric 4(4):309-311

Knage-Rasmussen KM, Houe H, Rousing T, Sorensen JT (2014) Herd- and sow-related risk factors for lameness in organic and conventional sow herds. Animal 8(1):121-127. https://doi.org/10.1017/s1751731113001900 
Knap PW (2009) Robustness. In: Resource allocation theory applied to farm animal production. WM Rauw (ed.) CABI Publ. Wallingford, UK, pp. 28Kongsted AG, Hermansen JE (2009) Sow body condition at weaning and reproduction performance in organic piglet production. Acta Agr Scand A-An 59(2):93-103. doi:https://doi.org/10.1080 /09064700903071768

Kongsted H, Hermansen JE (2009) Sow body condition at weaning and reproduction performance in organic piglet production. Acta Agr Scand A-An 59(2):93-103. https://doi.org/10.1080/09064700903071768

Kongsted H, Sørensen JT (2017) Lesions found at routine meat inspection on finishing pigs are associated with production system. Vet J 223:25-30. https://doi.org/10.1016/j. tvj1.2017.04.016

Kottferova J, Jakuba T, Marekova J, Kisova J, Fejsakova M, Ondrasovicova O (2014) Comparison of welfare of cows kept on organic and conventional farms using animal needs index system. J Cent Europ Agri 15(2):95-108

Kreinocker K, Sattler T, Hagmuller W, Hennig-Pauka I, Schmoll F (2017) Occurrence of antibodies against Toxoplasma, Leptospira and PRRSV and the incidence of Salmonella and Ascaris suum on organic pig fattening farms in Austria. Wien Tierarz Monats 104(7-8):221-228

Krieger M, Sjostrom K, Blanco-Penedo I, Madouasse A, Duval JE, Bareille N, Fourichon C, Sundrum A, Emanuelson U (2017) Prevalence of production disease related indicators in organic dairy herds in four European countries. Livest Sci 198:104-108. https://doi.org/10.1016/j.livsci.2017.02.015

Krieger M, Jones PJ, Blanco-Penedo I, Duval JE, Emanuelson U, Hoischen-Taubner S, Sjöström K, Sundrum A (2020) Improving animal health on organic dairy farms: stakeholders' view on policy options. Sustainability 12(7):3001. https://doi.org/10.3390/su12073001

Langford FM, Rutherford KMD, Sherwood L, Jack MC, Lawrence AB, Haskell MJ (2011) Behavior of cows during and after peak feeding time on organic and conventional dairy farms in the United Kingdom J Dairy Sci 94:746-753 doi: https://doi.org/10.3168/jds.2010-3309

Leach KA, Whay HR, Maggs CM, Barker ZE, Paul ES, Bell AK, Main DCJ (2010) Working towards a reduction in cattle lameness: 1. Understanding barriers to lameness control on dairy farms Res Vet Sci 89:311-317. https://doi.org/10.1016 j.rvsc.2010.02.014

Leeb C, Hegelund L, Edwards S, Mejer H, Roepstorff A, Rousing T, Sundrum A, Bonde M (2014) Animal health, welfare and production problems in organic weaner pigs. Org Agric 4(2): 123-133. https://doi.org/10.1007/s13165-013-0054-y

Leeb C, Rudolph G, Bochicchio D, Edwards S, Fruh B, Holinger M, Holmes D, Illmann G, Knop D, Prunier A, Rousing T, Winckler C, Dippel S (2019) Effects of three husbandry systems on health, welfare and productivity of organic pigs. Animal:1-9. https://doi.org/10.1017/s1751731119000041

Leenstra F, Maurer V, Galea F, Bestman M, Amsler-Kepalaite Z, Visscher J, Vermeij I, van Krimpen M (2014) Laying hen performance in different production systems; why do they differ and how to close the gap? Results of discussions with groups of farmers in The Netherlands, Switzerland and France, benchmarking and model calculations. Eur Poultry Sci 78. https://doi.org/10.1399/eps.2014.53
Leiber F, Dorn K, Probst JK, Isensee A, Ackermann N, Kuhn A, Spengler Neff A (2015) Concentrate reduction and sequential roughage offer to dairy cows: effects on milk protein yield, protein efficiency and milk quality. J Dairy Res 82(3):272278. https://doi.org/10.1017/S0022029915000205

Levison LJ, Miller-Cushon EK, Tucker AL, Bergeron R, Leslie KE, Barkema HW, DeVries TJ (2016) Incidence rate of pathogen-specific clinical mastitis on conventional and organic Canadian dairy farms. J Dairy Sci 99(2):1341-1350. https://doi.org/10.3168/jds.2015-9809

Lindgren Y, Lundeheim N, Boqvist S, Magnusson U (2013) Reproductive performance in pigs reared under organic conditions compared with conventionally reared pigs. Acta Vet Scand 55:4. https://doi.org/10.1186/1751-0147-55-33

Lindgren K, Bochicchio D, Hegelund L, Leeb C, Mejer H, Roepstorff A, Sundrum A (2014) Animal health and welfare in production systems for organic fattening pigs. Org Agric 4(2):135-147. https://doi.org/10.1007/s13165-014-0069-z

Lund V, Algers B (2003) Research on animal health and welfare in organic farming - a literature review. Livest Prod Sci 80:5568. https://doi.org/10.1016/S0301-6226(02)00321-4

Lund VP, Nielsen LR, Oliveira ARS, Christensen JP (2017) Evaluation of the Danish footpad lesion surveillance in conventional and organic broilers: misclassification of scoring. Poult Sci 96(7):2018-2028. https://doi.org/10.3382 $/ \mathrm{ps} / \mathrm{pex} 024$

Malissiova E, Papadopoulos T, Kyriazi A, Mparda M, Sakorafa C, Katsioulis A, Katsiaflaka A, Kyritsi M, Zdragas A, Hadjichristodoulou C (2017) Differences in sheep and goats milk microbiological profile between conventional and organic farming systems in Greece. J Dairy Res 84(2):206213. https://doi.org/10.1017/s0022029917000103

Martelli G, Valla H, Bucci D, Zaghini G, Vignola G, Sardi L (2010) Assessment of welfare and productive performance in dairy cows organically reared in plains or hilly areas. Anim Welf 19(1):17-23

May K, Brugemann K, Konig S, Strube C (2017) Patent gastrointestinal nematode infections in organically and conventionally pastured dairy cows and their impact on individual milk and fertility parameters. Vet Parasitol 245:119-127. https://doi.org/10.1016/j.vetpar.2017.08.024

Mederos A, Fernandez S, VanLeeuwen J, Peregrine AS, Kelton D, Menzies P, LeBoeuf A, Martin R (2010) Prevalence and distribution of gastrointestinal nematodes on 32 organic and conventional commercial sheep farms in Ontario and Quebec, Canada (2006-2008). Vet Parasitol 170(3-4):244 252. https://doi.org/10.1016/j.vetpar.2010.02.018

Mederos A, Waddell L, Sánchez J, Kelton D, Peregrine AS, Menzies P, VanLeeuwen J, Rajić A (2012) A systematic review-meta-analysis of primary research investigating the effect of selected alternative treatments on gastrointestinal nematodes in sheep under field conditions. Prev Vet Med 104(1):1-14

Mie A, Andersen HR, Gunnarsson S, Kahl J, Kesse-Guyot E, Rembialkowska E, Quaglio G, Grandjean P (2017) Human health implications of organic food and organic agriculture: a comprehensive review. Environ Health 16:22. https://doi. org/10.1186/s12940-017-0315-4

Morgan T, Pluske J, Miller D, Collins T, Barnes AL, Wemelsfelder F, Fleming PA (2014) Socialising piglets in lactation positively affects their post-weaning behaviour. 
Appl Anim Behav Sci 158:23-33. https://doi.org/10.1016/j. applanim.2014.06.001

Müller U, Sauerwein H (2010) A comparison of somatic cell count between organic and conventional dairy cow herds in West Germany stressing dry period related changes. Livest Sci 127(1):30-37. https://doi.org/10.1016/j.livsci.2009.08.003

Napolitano F, De Rosa G, Ferrante V, Grasso F, Braghieri A (2009) Monitoring the welfare of sheep in organic and conventional farms using an ANI $35 \mathrm{~L}$ derived method. Small Ruminant Res 83(1-3):49-57. https://doi.org/10.1016/j. smallrumres.2009.04.001

Newberry RC (2017) Chapter 9 - Commercial free-range egg production practices. In: Hester PY (ed) Egg innovations and strategies for improvements. Academic Press, San Diego, pp 89-102. https://doi.org/10.1016/B978-0-12800879-9.00009-3

Novobilský A, Sollenberg S, Höglund J (2015) Distribution of Fasciola hepatica in Swedish dairy cattle and associations with pasture management factors. Geospat Health 9:293-300

Öhlund E, Hammer M, Björklund J (2017) Managing conflicting goals in pig farming: farmers' strategies and perspectives on sustainable pig farming in Sweden. Int J Agri Sust 15(6): 693-707. https://doi.org/10.1080/14735903.2017.1399514

OIE (2019) World Organisation for Animal Health, 2019: terrestrial animal health code. Introduction to the recommendations for animal welfare, Chapter 7.1. https://www.oie. int/en/standard-setting/terrestrial-code/accessonline/?htmfile=chapitre_aw_introduction.htm

Olesen I, Groen AF, Gjerde B (2000) Definition of animal breeding goals for sustainable production systems. J Anim Sci 78(3):570-582. https://doi.org/10.2527/2000.783570x

Oltenacu PA, Broom DM (2010) The impact of genetic selection for increased milk yield on the welfare of dairy cows. Anim Welf 19(S):39-49

Orjales I, Mezo M, Miranda M, Gonzalez-Warleta M, Rey-Crespo F, Vaarst M, Thamsborg S, Dieguez FJ, Castro-Hermida JA, Lopez-Alonso M (2017) Helminth infections on organic dairy farms in Spain. Vet Parasitol 243:115-118. https://doi.org/10.1016/j.vetpar.2017.06.031

Orjales I, Herrero-Latorre C, Mira M, Rey-Crespo F, RodriguezBermudez R, Lopez-Alonso M (2018) Evaluation of trace element status of organic dairy cattle. Animal 12(6):12961305. https://doi.org/10.1017/S1751731117002890

Ouzzani M, Hammady H, Fedorowicz Z, Elmagarmid A (2016) Rayyan - a web and mobile app for systematic reviews. Systematic Reviews 5:210. https://doi.org/10.1186/s13643016-0384-4

Papatsiros VG (2011) Impact of animal health management on organic pig farming in Greece. Biotechn Anim Husbandry 27(1):115-125. https://doi.org/10.2298/bah1101115p

Pilarczyk B, Balicka-Ramisz A, Ramisz A, Binerowska B (2008) Comparison of internal parasite invasions in sheep on ecological and conventional farms. Ann Anim Sci 8(1):89-93

Pinedo P, Velez J, Manriquez D, Bothe H (2017) Treatment options for lameness disorders in organic dairies. Vet Clin N AM-Food A 33(2):377-387. https://doi.org/10.1016/j. cvfa.2017.03.003

Poizat A, Bonnet-Beaugrand F, Rault A, Fourichon C, Bareille N (2017) Antibiotic use by farmers to control mastitis as influenced by health advice and dairy farming systems. Prev Vet
Med 146:61-72. https://doi.org/10.1016/j. prevetmed.2017.07.016

Presto Åkerfeldt M, Nihlstrand J, Neil M, Lundeheim N, Andersson HK, Wallenbeck A (2019) Chicory and red clover silage in diets to finishing pigs - influence on performance, time budgets and social interactions. Org Agric 9(1):127-138

Presto M, Rundgren M, Wallenbeck A (2013) Inclusion of grass/ clover silage in the diet of growing/finishing pigs - influence on pig time budgets and social behaviour. Acta Agr ScandAAn 63(2):84-92. https://doi.org/10.1080 /09064702.2013.793734

Prunier A, Dippel S, Bochicchio D, Edwards S, Leeb C, Lindgren K, Sundrum A, Dietze K, Bonde M (2014) Characteristics of organic pig farms in selected European countries and their possible influence on litter size and piglet mortality. Org Agric 4(2):163-173. https://doi.org/10.1007/s13165-0130040-4

Rangstrup-Christensen L, Krogh MA, Pedersen LJ, Sorensen JT (2017) Sow-level risk factors for stillbirth of piglets in organic sow herds. Animal 11(6):1078-1083. https://doi. org/10.1017/s1751731116002408

Rangstrup-Christensen L, Krogh MA, Pedersen LJ, Sorensen JT (2018a) Sow level risk factors for early piglet mortality and crushing in organic outdoor production. Animal 12(4):810 818. https://doi.org/10.1017/s1751731117002178

Rangstrup-Christensen L, Schild SLA, Pedersen LJ, Sorensen JT (2018b) Causes of preweaning mortality in organic outdoor sow herds. Research in Vet Scie 118:171-180. https://doi. org/10.1016/j.rvsc.2018.02.010

Rezaei M, Yngvesson J, Gunnarsson S, Jönsson L, Wallenbeck A (2018) Feed efficiency, growth performance, and carcass characteristics of a fast- and a slower-growing broiler hybrid fed low- or high-protein organic diets. Org Agric 8(2):121128. https://doi.org/10.1007/s13165-017-0178-6

Richards GJ, Wilkins LJ, Knowles TG, Booth F, Toscano MJ, Nicol CJ, Brown SN (2012) Pop hole use by hens with different keel fracture status monitored throughout the laying period. Vet Rec 170(19). https://doi.org/10.1136/vr.100489

Richert RM, Cicconi KM, Gamroth MJ, Schukken YH, Stiglbauer KE, Ruegg PL (2013a) Risk factors for clinical mastitis, ketosis, and pneumonia in dairy cattle on organic and small conventional farms in the United States. J Dairy Sci 96(7): 4269-4285. https://doi.org/10.3168/jds.2012-5980

Richert RM, Cicconi KM, Gamroth MJ, Schukken YH, Stiglbauer KE, Ruegg PL (2013b) Perceptions and risk factors for lameness on organic and small conventional dairy farms. J Dairy Sci 96(8):5018-5026. https://doi.org/10.3168 /jds.2012-6257

Rodenburg TB, Van Krimpen MM, De Jong IC, De Haas EN, Kops MS, Riedstra BJ, Nordquist RE, Wagenaar JP, Bestman M, Nicol CJ (2013) The prevention and control of feather pecking in laying hens: identifying the underlying principles. World's Poult Sci J 69(2):361-374. https://doi. org/10.1017/S0043933913000354

Rodriguez-Bermudez R, Mira M, Orjales I, Rey-Crespo F, Munoz N, Lopez-Alonso M (2017) Holstein-Friesian milk performance in organic farming in North Spain: comparison with other systems and breeds. Span J Agric Res 15(1):10. https://oi.org/10.5424/sjar/2017151-10037

Roepstorff A, Mejer H, Nejsum P, Thamsborg S.M (2011) Helminth parasites in pigs: New challenges in pig production 
and current research highlights. Vet Parasitol 180:72-81. https://doi.org/10.1016/j.vetpar.2011.05.029

Röös E, Mie A, Wivstad M, Salomon E, Johansson B, Gunnarsson S, Wallenbeck A, Hoffmann R, Nilsson U, Sundberg C, Watson CA (2018) Risks and opportunities of increasing yields in organic farming. A review. Agron Sustain Dev 38(2):14. doi: https://doi.org/10.1007/s13593-018-0489-3

Rutherford KMD, Langford FM, Jack MC, Sherwood L, Lawrence AB, Haskell MJ (2008) Hock injury prevalence and associated risk factors on organic and nonorganic dairy farms in the United Kingdom. J Dairy Sci 91(6):2265-2274. https://doi.org/10.3168/jds.2007-0847

Rutherford KMD, Langford FM, Jack MC, Sherwood L, Lawrence AB, Haskell MJ (2009) Lameness prevalence and risk factors in organic and non-organic dairy herds in the United Kingdom. Vet J 180(1):95-105. https://doi. org/10.1016/j.tvj1.2008.03.015

Sanders J (ed) (2013) Evaluation of the EU legislation on organic farming. Thünen Institute of Farm Economics, Braunschweig https://orgprints.org/28713/1/Final_ StudyReport_\%28BlackWhite\%29.pdf

Sarica M, Yamak̄ US, Boz MA (2014) Effect of production systems on foot pad dermatitis (FPD) levels among slow-, medium- and fast-growing broilers. Eur Poultry Sci 78. https://doi.org/10.1399/eps.2014.52

Schwendel BH, Wester TJ, Morel PCH, Tavendale MH, Deadman C, Shadbolt NM, Otter DE (2015) Invited review: organic and conventionally produced milk - an evaluation of factors influencing milk composition. J Dairy Sci 98:721-746. https://doi.org/10.3168/jds.2014-8389

Sherwin CM, Nasr MAF, Gale E, Petek M, Stafford K, Turp M, Coles and GC (2013) Prevalence of nematode infection and faecal egg counts in free-range laying hens: relations to housing and husbandry. Br Poult Sci 54(1): 12-23. doi: https://doi.org/10.1080/00071668.2012.757577

Silverlås C, Emanuelson U, de Verdier K, Björkman C (2009) Prevalence and associated management factors of Cryptosporidium shedding in 50 Swedish dairy herds. Prev Vet Med 90(3):242-253. https://doi.org/10.1016/j. prevetmed.2009.04.006

Simoneit C, Bender S, Koopmann R (2012) Quantitative and qualitative overview and assessment of literature on animal health in organic farming between 1991 and 2011-Part II: pigs, poultry, others. Landbauforschung-Ger 62(3):105-110

Sjöstrom K, Fall N, Blanco-Penedo I, Duval JE, Krieger M, Emanuelson U (2018) Lameness prevalence and risk factors in organic dairy herds in four European countries. Livest Sci 208:44-50. https://doi.org/10.1016/j.livsci.2017.12.009

Skomorucha I, Sosnowka-Czajka E (2017) Physiological parameters in broiler chickens reared under different housing systems during a period of high temperatures. Acta Sci Pol Zootech 16(3):25-34

Slagboom M, Kargo M, Edwards D, Sørensen AC, Thomasen JR, Hjortø L (2016) Organic dairy farmers put more emphasis on production traits than conventional farmers. J Dairy Sci 99(12):9845-9856. https://doi.org/10.3168/jds.2016-11346

Sørensen JT, Pedersen LJ (2013) Status, årsager og udfordringer i forhold til løsning af forhøjet dødelighed hos økologiske pattegrise. DCA rapport 021 (in Danish), Aarhus University, Tjele, Denmark. Available: https://pure.au. dk/ws/files/56329628/Pattegrised_delighed.pdf
Sorge US, Moon RD, Stromberg BE, Schroth SL, Michels L, Wolff LJ, Kelton DF, Heins BJ (2015) Parasites and parasite management practices of organic and conventional dairy herds in Minnesota. J Dairy Sci 98(5):3143-3151. https://doi.org/10.3168/jds.2014-9031

Stiglbauer K, Cicconi-Hogan K, Richert R, Schukken Y, Ruegg P, Gamroth M (2013) Assessment of herd management on organic and conventional dairy farms in the United States. J Dairy Sci 96:1290-1300

Stuoge I, Ribikauskas V, Ribikauskiene D, Juodka R, Jomantas Z (2016) Estimation of beef and dairy cattle welfare in organic farms of Lithuania. Bulg J Agric Sci 22(3):477-481

Sundberg T, Rydhmer L, Fikse WF, Berglund B, Strandberg E (2010) Genotype by environment interaction of Swedish dairy cows in organic and conventional production systems. Acta Agr ScandA-An 60(2):65-73. https://doi.org/10.1080 /09064702.2010.496003

Sundrum A (2001) Organic livestock farming. Livest Prod Sci 67(3):207-215. https://doi.org/10.1016/S0301-6226(00 )00188-3

Sundrum A (2014) Organic livestock production. In: van Alfen NK (ed) Encyclopedia of agriculture and food systems. Academic Press, Oxford, pp 287-303

Sundrum A, Goebel A, Bochicchio D, Bonde M, Bourgoin A, Cartaud G, Dietze K, Dippel S, Gunnarsson S, Hegelund L, Leeb C, Lindgren K, Prunier A, Wiberg S (2010) Health status in organic pig herds in Europe. Proc of the 21st Int Pig Veterinary Society (IPVS) Congress, July 18-21, 2010. Vancouver, Canada, p 277

Sutherland MA, Webster J, Sutherland I (2013) Animal health and welfare issues facing organic production systems. Animals 3 : 1021-1035. https://doi.org/10.3390/ani3041021

Szulc K (2011) Welfare of pigs in organic production system assumptions and their implementation. J Res Appl Agric Engineer 56(4):143-147

Tahamtani FM, Hinrichsen LK, Riber AB (2018) Welfare assessment of conventional and organic broilers in Denmark, with emphasis on leg health. Vet Rec 183(6):7. https://doi. org/10.1136/vr.104817

Terlouw C, Berne A, Astruc T (2009) Effect of rearing and slaughter conditions on behaviour, physiology and meat quality of Large White and Duroc-sired pigs. Livest Sci 122(2):199-213

Thapa S, Hinrichsen LK, Brenninkmeyer C, Gunnarsson S, Heerkens JLT, Verwer C, Niebuhr K, Willett A, Grilli G, Thamsborg SM, Sorensen JT, Mejer H (2015) Prevalence and magnitude of helminth infections in organic laying hens (Gallus gallus domesticus) across Europe. Vet Parasitol 214(1):118-124. https://doi.org/10.1016/j. vetpar.2015.10.009

Thomsson O, Sjunnesson Y, Magnusson U, Eliasson-Selling L, Wallenbeck A, Bergqvist AS (2016) Consequences for piglet performance of group housing lactating sows at one, two, or three weeks post-farrowing. PLoS One 11(6). https://doi. org/10.1371/journal.pone.0156581

Toma L, Stott AW, Heffernan C, Ringrose S, Gunn GJ (2013) Determinants of biosecurity behaviour of British cattle and sheep farmers-a behavioural economics analysis. Prev Vet Med 108(4):321-333. https://doi.org/10.1016/j. prevetmed.2012.11.009 
Turner (2011) Breeding against harmful social behaviours in pigs and chickens: state of the art and the way forward. Appl Anim Behav Sci 134:1-9. https://doi.org/10.1016/j. applanim.2011.06.001

Turpin DL, Langendijk P, Plush K, Pluske JR (2017) Intermittent suckling with or without co-mingling of non-littermate piglets before weaning improves piglet performance in the immediate post-weaning period when compared with conventional weaning. J Anim Sci Biotech 8(14). https://doi. org/10.1186/s40104-017-0144-x

Tuyttens F, Heyndrickx M, de Boeck M, Moreels A, van Nuffel A, van Poucke E, van Coillie E, van Dongen S, Lens L (2008) Broiler chicken health, welfare and fluctuating asymmetry in organic versus conventional production systems. Livest Sci $113(2-3): 123-132$. https://doi.org/10.1016/j. livsci.2007.02.019

Vaarst M, Alrøe HF (2012) Concepts of animal health and welfare in organic livestock systems. J Agric Environ Ethics 25:333347. https://doi.org/10.1007/s10806-011-9314-6

van de Weerd HA, Keatinge R, Roderick S (2009) A review of key health-related welfare issues in organic poultry production. Worlds Poult Sci J 65(4):649-684. https://doi.org/10.1017 /s0043933909000464

van Nieuwamerongen SE, Bolhuis JE, van der Peet-Schwering CMC, Soede NM (2014) A review of sow and piglet behaviour and performance in group housing systems for lactating sows. Animal 8(3):448-460

van Nieuwamerongen SE, Soede NM, van der Peet-Schwering CMC, Kemp B, Bolhuis JE (2015) Development of piglets raised in a new multi-litter housing system vs. conventional single-litter housing until 9 weeks of age. J Anim Sci 93(11): 5442-5454

van Wagenberg CPA, de Haas Y, Hogeveen H, van Krimpen MM, Meuwissen MPM, van Middelaar CE, Rodenburg TB (2017) Animal board invited review: comparing conventional and organic livestock production systems on different aspects of sustainability. Animal 11(10):1839-1851. https://doi. org/10.1017/S175173111700115X

Verdon M, Morrison RS, Hemsworth PH (2016) Rearing piglets in multi-litter group lactation systems: effects on piglet aggression and injuries post-weaning. Appl Anim Behav Sci 183:35-41

Verdon M, Morrison RS, Rault JL (2019) Group lactation from 7 or 14 days of age reduces piglet aggression at weaning compared to farrowing crate housing. Animal 13(10):23272335. https://doi.org/10.1017/S1751731119000478

Verhoog H (2000) Defining positive welfare and animal integrity. In: Hovi M, Garcia Trujillo R (eds) Diversity of livestock systems and definition of animal welfare. University of Reading, Reading, pp 108-119

Verhoog, H, Lund, Vonne and Alrøe, Hugo Fjelsted (2004) Animal welfare, ethics and organic farming. In: Vaarst, Mette; Roderick, Steve; Lund, Vonne and Lockerets, William (Eds.) Animal health and welfare in organic agriculture. CABI Publishing, chapter 5, pp. 73-94

Verkaik J (2011) in: M.B.M. Bracke (Ed.) et al. Verbeteren welzijnsprestaties in de biologische veehouderij: Korte termijn prioriteiten en aanzet tot lange termijn visie (English title: Improving welfare performance in organic farming: Short term priorities and long term vision). Report
479, Wageningen UR Livestock Research, Lelystad, The Netherlands. ISSN 1570-8616

Vik SG, Oyrehagen O, Boe KE (2017) Effect of space allowance and flooring on the behavior of pregnant ewes. J Anim Sci 95(5):2032-2040. https://doi.org/10.2527/jas.2016.1341

von Keyserlingk MAG, Cestari AA, Franks B, Fregonesi JA, Weary DM (2017) Dairy cows value access to pasture as highly as fresh feed. https://doi.org/10.1038/srep44953

Wallander C, Frössling J, Dórea FC, Uggla A, Vågsholm I, Lundén A (2016) Pasture is a risk factor for Toxoplasma gondii infection in fattening pigs. Vet Parasitol 224:27-32. https://doi.org/10.1016/j.vetpar.2016.05.005

Wallenbeck A, Gustafson G, Rydhmer L (2009a) Sow performance and maternal behaviour in organic and conventional herds. Acta Agr Scand A-An 59(3):181-191. https://doi. org/10.1080/09064700903307824

Wallenbeck A, Rydhmer L, Lundeheim N (2009b) GxE interactions for growth and carcass leanness: re-ranking of boars in organic and conventional pig production. Livest Sci 123(23):154-160. https://doi.org/10.1016/j.livsci.2008.11.003

Wallenbeck A, Wilhelmsson S, Jönsson L, Gunnarsson S, Yngvesson J (2017) Behaviour in one fast-growing and one slower-growing broiler (Gallus gallus domesticus) hybrid fed a high- or low-protein diet during a 10-week rearing period. Acta Agr Scand A-An66(3):1-9. doi:https://doi.org/10.1080 /09064702.2017.1303081

Wallenbeck A, Eliasson C, Lundeheim N (2020) Leg health, growth and carcass characteristics in growing-finishing pigs of two different genotypes reared on Swedish organic farms. Org Agric 10:97-103. https://doi.org/10.1007/s13165-01900260-8

Weissensteiner R, Baldinger L, Hagmuller W, Zollitsch W (2018) Effects of two $100 \%$ organic diets differing in proportion of home-grown components and protein concentration on performance of lactating sows. Livest Sci 214:211-218. https://doi.org/10.1016/j.livsci.2018.06.006

Werner C, Schubbert A, Schrodl W, Kruger M, Sundrum A (2014) Effects of feeding different roughage components to sows in gestation on bacteriological and immunological parameters in colostrum and immune response of piglets. Arch Anim Nutr 68(1):29-41

Westin R, Holmgren N, Hultgen J, Ortman K, Linder A, Algers B (2015) Post-mortem findings and piglet mortality in relation to strategic use of straw at farrowing. Prev Vet Med 119:141152. https://doi.org/10.1016/j.prevetmed.2015.02.023

Wierup M, Wahlström H, Lahti E, Eriksson H, Jansson DS, Odelros Å, Ernholm L (2017) Occurrence of Salmonella spp.: a comparison between indoor and outdoor housing of broilers and laying hens. Acta Vet Scand 59(1):13. https://doi.org/10.1186/s13028-017-0281-4

Wilhelmsson S, Yngvesson J, Jonsson L, Gunnarsson S, Wallenbeck A (2019) Welfare Quality ${ }^{\circledR}$ assessment of a fast-growing and a slower-growing broiler hybrid, reared until 10 weeks and fed a low-protein, high-protein or mussel-meal diet. Livest Sci 219:71-79. https://doi. org/10.1016/j.livsci.2018.11.010

Williams AR (2011) Immune-mediated pathology of nematode infection in sheep - is immunity beneficial to the animal? Parasitology 138(5):547-556. https://doi.org/10.1017 /s0031182010001654 
Winter JR, Kaler J, Ferguson E, KilBride AL, Green LE (2015) Changes in prevalence of, and risk factors for, lameness in random samples of English sheep flocks: 2004-2013. Prev Vet Med 122(1):121-128. https://doi.org/10.1016/j. prevetmed.2015.09.014

Wnuk-Gnich A, Lukasiewicz M, Niemiec J, Mroczek-Sosnowska N (2016) The effect of a housing system on production results and slaughter analysis of slow-growing chickens. Annals of Warsaw University of Life Sciences - SGGW, Anim Sci 55:309-318

Wolff C, Emanuelson U, Ohlson A, Alenius S, Fall N (2015) Bovine respiratory syncytial virus and bovine coronavirus in Swedish organic and conventional dairy herds. Acta Vet Scand 57(2). https://doi.org/10.1186/s13028-014-0091-x
Yngvesson J, Wedin M, Gunnarsson S, Jonsson L, Blokhuis H, Wallenbeck A (2017) Let me sleep! Welfare of broilers (Gallus gallus domesticus) with disrupted resting behaviour. Acta Agr Scand A-An 67(3-4):123-133. https://doi. org $/ 10.1080 / 09064702.2018 .1485729$

Zoiopoulos P, Hadjigeorgiou I (2013) Critical overview on organic legislation for animal production: towards conventionalization of the system? Sustainability 5:3077-3094. https://doi. org/10.3390/su5073077

Publisher's note Springer Nature remains neutral with regard to jurisdictional claims in published maps and institutional affiliations. 